\title{
IMPLEMENTING GLOBAL ANTI-BRIBERY NORMS: FROM THE FOREIGN CORRUPT PRACTICES ACT TO THE OECD ANTI-BRIBERY CONVENTION TO THE U.N. CONVENTION AGAINST CORRUPTION
}

\begin{abstract}
Elizabeth K. Spahn*
The thirty-fifth anniversary of the US Foreign Corrupt Practices Act ("FCPA") ${ }^{1}$ is an opportune time to note the very successful globalization of values embodied in this remarkable statute. When the FCPA was first enacted in 1978, the United States stood alone in criminalizing bribes paid to foreign officials to obtain business abroad. By 2012, thirty-nine major economic powers have ratified the OECD Anti-Bribery Convention ${ }^{2}$ and 165 nations are states parties ${ }^{3}$ to the United Nations Convention Against Corruption. ${ }^{4}$
\end{abstract}

\section{EVOLVING NORMS INFLUENCING THE US FCPA}

Centuries of colonial experience by Western powers were based on the premise that global trade required bribing local "black tyrants" as the former British Governor General of Bengal, circa 1787, indelicately put it. ${ }^{5}$

* C 2012. Professor of Law, New England Law | Boston. My thanks to Barbara Fredericks, Melanie Reed, Jessica Tillipman; research assistants Alaina Anderson, Louisa Gibbs, and Nikolaus Schuttauf; research librarians Barry Stearns, Helen Litwick, and Brian Flaherty; and to Angela Cheung for assistance in the power point presentation. Errors are mine alone. I can be contacted at espahn@nesl.edu.

1. Foreign Corrupt Practices Act of 1977, Pub. L. No. 95-213, 91 Stat. 1494 (1977) (codified as amended at 15 U.S.C. $\$ \$$ 78dd-1 et seq.) [hereinafter FCPA].

2. See Organisation for Economic Co-operation and Development, Convention on Combating Bribery of Foreign Public Officials in International Business Transactions, Dec. 18, 1997, S. TREATY DOC. No. 105-43, 37 I.L.M. 1, available at http://www.oecd.org/investment/ briberyininternationalbusiness/anti-briberyconvention/38028044.pdf [hereinafter Convention on Combating Bribery]; ORg. FOR ECON. CO-OPERATION AND DEV., OECD CONVENTION ON COMBATING BRIBERY OF Forfign PUBLIC OfFICIALS IN INTERNATIONAL BUSINESS TRANSACTIONS: RATIFICATION STATUS AS OF APRIL 2012 (2012), available at http://www.oecd.org/daf/ briberyininternationalbusiness/anti-briberyconvention/40272933.pdf.

3. United Nations Convention Against Corruption: UNCAC Signature and Ratification Status, UNITED NATIONS OFF. ON DRUGS AND CRIME, http://www.unodc.org/unodc/en/ treaties/CAC/signatories.html (last visited Jan. 23, 2013).

4. See United Nations Off. on Drugs and Crime, United Nations Convention AGAINST CORRUPTION (2004), available at http://www.unodc.org/documents/treaties/ UNCAC/Publications/Convention/08-50026_E.pdf.

5. Padideh Ala'i, The Legacy of Geographical Morality and Colonialism: $A$ Historical Assessment of the Current Crusade Against Corruption, 33 Vand. J. TransnaT'L L. 877, 884-85 (2000). Professor Ala'i's primary source of legal history analyzes the British House of Commons impeachment and British House of Lords trial of the Governor-General of Bengal, Warren Hastings. Id. at 833. The use of racial stereotyping was endemic by those 
Bribing home country officials was unacceptable in "civilized" Christian (white) Western nations during that era. ${ }^{6}$ The racial, religious, and cultural double standard of that era was stark, and it is today unacceptable. ${ }^{7}$

The anti-corruption norm, of course, is deeply embedded in American culture from the time of our own colonization by the British Empire. Anticorruption sentiment was an important impetus for the American Revolution itself. The infamous seditious libel trial of New York newspaper editor John Peter Zenger is often cited for its importance in developing First Amendment free speech and free press law, as well as for its importance in establishing jury trial as a fundamental American right. ${ }^{8}$

But it should never be forgotten that what triggered the arrest in the first place was John Peter Zenger publishing articles about the corruption of British colonial Governor of New York William Cosby. ${ }^{9}$ Alexander Hamilton made his New York legal debut by successfully defending printer Zenger. ${ }^{10}$ Free press advocates note that thirty-five percent of journalists

who defended the practice of bribery abroad as well as by anti-bribery reformers. Hastings specifically recruited "black tyrants" to run his operations in Bengal because, in Hastings' view, they were easier to control and intimidate than the licentious and debauched expatriated whites. See id.

6. Elizabeth Spahn, International Bribery: The Moral Imperialism Critiques, 18 MINN. J. INT'L L. 155, 189-90 (2009). [hereinafter Spahn, Moral Imperialism Critiques].

7. Id. at 190-91.

8. See, e.g., Kathleen M. Sullivan \& Gerald Gunther, ConstTtutional Law 76263 (17th ed. 2010).

9. The British Governor of New York, William Cosby, was "quick-tempered, haughty, unlettered, jealous, and above all greedy" according to his political opponents. See JAMES alexander, A Brief Narrative of the Case and Trial of John Peter Zenger, Printer OF THE NEW-YORK WEeKLY JoURNAL 2 (Stanley Katz ed., Harvard Univ. Press $2 d$ ed. 1972). Governor Cosby arrived in New York after removal from a post in Minorca where he had been accused of various crimes of extortion by the native aristocracy. See WiLliam L. Putnam, John Peter Zenger and the Fundamental Freedom 21-22 (1997) ("Colonial governors consisted 'most often of members of aristocratic families whose personal morals, or whose incompetence, were such that it was impossible to employ them nearer home."'); see also Paul Finkelman, Politics, the Press, and the Law: The Trial of John Peter Zenger, in AMERICAN Political Trials 25, 26 (Michael R. Belknap ed., 1994) (describing Governor Cosby as "venal and overbearing").

Governor Cosby was embroiled in political disputes over the spoils of the governorship with Rip Van Dam of the Dutch New York clans, eventually alienating the powerful Morris family. Cosby stripped Lewis Morris of the prestigious Chief Justice position after Morris refused to render an opinion in favor of Cosby, thereby launching the political vendettas culminating in the trial of orphan printer and general good guy John Peter Zenger. See AlEXANDER, supra, at 3-6. My thanks to Barry Stearns for this research.

10. Zenger's lawyers James Alexander and William Smith were the leading lawyers in New York. They were disbarred after challenging the authority of two Supreme Court judges appointed by Governor Cosby. ALEXANDER, supra note 9, at 18-19. The scarcity of New York lawyers forced the Morris faction to look to Philadelphia lawyer Alexander Hamilton, reputedly the "best lawyer in America." Id. at 21. Bostonians of course believe John Adams to be the best lawyer of that era in America. We all agree that Alexander Hamilton was a very fine lawyer. Hamilton won the Zenger case, articulating what would eventually become 
killed worldwide since 1992 are reporting on crime and corruption at the time of death. ${ }^{11}$

Yet despite evolving norms regarding racial and cultural double standards during the eras of decolonization and desegregation, bribing foreign officials to get business done abroad remained astonishingly commonplace. The impetus for change came about not from human rights or decolonization anti-imperialism activists but rather from a most unlikely source, a US Securities and Exchange Commission ("SEC") prosecutor.

Stanley Sporkin, an attorney and certified public accountant, was Director of Enforcement for the SEC during the Republican administrations of Presidents Nixon and Ford, known today as the Watergate era of the 1970 s. $^{12}$ Puzzled by testimony regarding illegal campaign contributions by corporations to the Committee to Re-Elect President Nixon ("CREEP"), Sporkin began investigating how those illegal payments were recorded in the corporate books. ${ }^{13} \mathrm{He}$ discovered foreign as well as domestic payments. ${ }^{14}$ "[O]ver 400 U.S. [sic] companies admitted making questionable or illegal payments in excess of $\$ 300$ million to foreign government officials, politicians and political parties. This included 117 of the top Fortune 500 corporations." 15 While not everybody was bribing to obtain business abroad prior to the FCPA, it appeared that about twentyfour percent of Fortune 500 companies were admitted bribe payers prior to the enactment of the FCPA.

\section{A. Morality and Efficient Free Market Competition}

The early norms of the FCPA did not emphasize the racial or colonial double-standard problem. In the earliest phase, two normative values were articulated-morality and efficient free market competition. The 1977 House Report stated:

It [bribery] is counter to the moral expectations and values of the American public. But not only is it unethical, it is bad business as well. It erodes public confidence in the integrity of the free market system. . . . [I]t rewards corruption instead of efficiency and puts pressure on ethical

\footnotetext{
American values of free speech and free press. Central among them is the right to criticize the overlords for corruption.

11. Frank Smyth, Comm. to Protect Journalists, CPJ Journalist Security Guide: Covering the News in a Dangerous and Changing World 28 (2012), available at http://cpj.org/security/guide.pdf.

12. Stanley Sporkin, The Worldwide Banning of Schmiergeld: A Look At the Foreign Corrupt Practices Act on its Twentieth Birthday, 18 Nw. J. INT'L L. \& Bus. 269, 271 (1998).

13. $I d$.

14. Id. at 272 .

15. $I d$.
} 
enterprises to lower their standards or risk losing business 16

The twin values, morality ${ }^{17}$ and free market competition, provided the initial bases for enacting the FCPA. The economic impact on American business was perceived by many at that time as enhanced if bribery abroad could be eliminated.

Early economic research, led by Susan Rose-Ackerman of Yale, reflected an emerging view that bribery causes more economic harm than it fixes. ${ }^{18}$ Allowing American businesses to compete on the merits, freed from the inefficient and unproductive expense of bribery, would enhance American competitiveness abroad.

\section{B. Unfair Competition - Leveling the Playing Field}

Although the 1977 House Report cited several examples of American businesses competing successfully abroad without bribing, ${ }^{19}$ complaints from the business sector became more insistent. Led by General Electric's General Counsel, Fritz Heimann, ${ }^{20}$ by 1988 the normative discussion

16. H.R. REP. No. 95-640, at 4-5 (1977).

17. Every legal system and every major religion condemns bribery, dating back to the Code of Hammurabi, which prohibits bribing judges. John Noonan in his landmark book Bribes leads the scholarship in this area. See generally JOHN T. NOONAN, BRIBES (1984); see also Spahn, Moral Imperialism Critiques, supra note 6.

18. See generally SUSAN ROSE ACKERMAN, CorruPtion: A STUdy IN Political Economy (1978). See also Joseph Nye, Corruption and Political Development: A CostBenefit Analysis, in Political CoRruption: REAdings In ComparatTVE ANalysis 566-67 (Arnold J. Heidenheimer ed., 1978); Nathaniel H. Leff, Economic Development through Bureaucratic Corruption, 8(3) AM. BEHAV. SCIENTIST 8, 8-14 (1964); Colin Leys, What is the Problem about Corruption?, 3(2) J. OF MODERN AFR. STUD. 215, 215-30 (1965); James C. Scott, The Analysis of Corruption in Developing Nations, 11 CoMP. STUD. IN SOC'Y \& HIST. 315, 315-41 (1969). By the late 1970s, many leading economists rejected an earlier 1960's view that bribery 'greases the wheels' of commerce. Elizabeth Spahn, Nobody Gets Hurt?, 41 GEO. J. INT'L L. 861, 864-869 (2010) [hereinafter Spahn, Nobody Gets Hurt?] (providing an overview of research by economists on the negative impacts of bribery). Modern economists by 2013 as I write have largely reached a consensus that bribery causes very substantial macro and micro-economic harm, especially when the impact of bribery is viewed over a longer time period than a single or short-term transaction.

19. See H.R. REP. No. 95-640, at 5 (1977); see also Omnibus Trade and Competitiveness Act of 1988, Pub. L. No. 100-418, § 5003(d)(2)(A)(ii), 102 Stat. 1107 (1988) (requiring the President to report to Congress on actions that might be taken in the event that negotiations failed to "eliminate any competitive disadvantage of United States businesses").

20. See Kenneth W. Abbott \& Duncan Snidal, Values and Interests: International Legalization in the Fight Against Corruption, 31 J. LEGAL STUD. 141, 154 (2002); see also Barbara Crutchfield George et al., The 1998 OECD Convention: An Impetus for Worldwide Changes in Attitudes Toward Corruption in Business Transactions, 37 AM. Bus. L.J. 485, 
shifted to establishing a competitive "level playing field" for all business globally. ${ }^{21}$

Rather than abolish the FCPA when facing unfair bribe-based competition from abroad, influential US business leaders of the 1980s era sought to extend anti-bribery norms to their non-US competitors. ${ }^{22}$ A cynic might view the effort to extend anti-corruption norms rather than reduce them as realpolitik, recognition that norms tend to be sticky; few politicians want to be caught voting to protect bribery.

However, the facts show that Mr. Heimann, General Electric's General Counsel-a leader in the US Chamber of Commerce - was also a founding member of the US chapter of Transparency International, the early leading non-governmental organization challenging global corruption. ${ }^{23}$ His active work for Transparency International continued long after he retired from General Electric. ${ }^{24}$ Apparently, some American business leaders of that era believed that global anti-corruption norms were in their best business interests as well as morally correct. ${ }^{25}$

Concern about unfair competition by non-US businesses permitted to bribe abroad (and in some cases to deduct foreign but of course not domestic bribes ${ }^{26}$ ) was a normative approach gaining momentum in the United States. This shift in emphasis might be viewed as the origins of effective globalization of FCPA norms of morality and efficient competitive free markets as described by the 1977 House Report.

The 1988 Amendments to the FCPA directed the US Executive Branch to negotiate with the Organization for Economic Cooperation and Development ("OECD") ${ }^{27}$ for an anti-bribery convention binding all OECD member states. ${ }^{28}$ (The OECD is a multi-lateral organization including

496 (2000) (describing the various positions of European governments during the initial

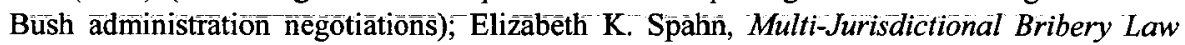
Enforcement: The OECD Anti-Bribery Convention, 53 VA. J. INT'L L. 1, 10-11 (2013) [hereinafter Spahn, Multi-Jurisdictional Bribery].

21. Sporkin, supra note 12, at 275-76; see also Spahn, Multi-Jurisdictional Bribery, supra note 20.

22. Sporkin, supra note 12, at 273.

23. See infra notes $45-50$ and accompanying text discussing the founding of Transparency International.

24. See generally International Chamber of COMmerce, Fighting CORRuPtion: INTERNATIONAL CORPORATE INTEGRITY HANDBOOK (Francois Vincke \& Fritz Heimann eds., 3rd ed. 2008).

25. $I d$.

26. For a more detailed discussion of the tax treatment of bribes in various OECD nations prior to adoption of the OECD Convention, see Elizabeth Spahn, Local Law Provisions Under the OECD Anti-Bribery Convention, 39 SYRACUSE J. INT'L L \& COM. 249, 261-65 (2012) [hereinafter Spahn, Local Law Provisions].

27. Omnibus Trade and Competitiveness Act of 1988, Pub. L. No. 100-418, $\S 5003(d)(1), 102$ Stat. 1107, 1107-1574 (codified as amended at 15 U.S.C. $\S \S 78 d d-1$ (1994)).

28. See, e.g., Convention on Combating Bribery, supra note 2. 
almost all the most economically powerful nations. ${ }^{29}$ ) Two US administrations attempted to convince major OECD economic powers such as the United Kingdom, Japan, Canada, France, and Germany to adopt an anti-bribery convention. ${ }^{30}$ The negotiation strategies employed by President George Herbert Walker Bush (Republican) and President Bill Clinton (Democrat) are amusing as well as notable.

A series of domestic political corruption scandals in Europe, combined with the Clinton administration's hardball tactics (reportedly threatening to disclose to the press names of OECD nation's corporations as the world's top bribe payers ${ }^{31}$ ) eventually led to the adoption of the OECD Anti-Bribery Convention in $1998 .^{32}$

The normative discussion also broadened during the Clinton administration. In addition to general morality, appeals to rational, competitive free markets, and leveling the playing field for global business, by 1998 the discourse expanded to include two additional norms development economics and respect for local (foreign) law.

\section{Democracy and Development}

The fourth normative justification for globalizing FCPA values by 1998 included economic development, ${ }^{33}$ apparently influenced by the US Department of State. ${ }^{34}$ Economic research correlating bribery with adverse

29. See generally Members and Partners, ORG. FOR ECON. CO-OPERATION AND DEV., http://www.oecd.org/about/membersandpartners/ (last visited Jan. 23, 2013).

30. Abbott \& Snidal, supra note 20 , at 162.

31. Id. at 164-66.

32. See Convention on Combating Bribery, supra note 2; see also THE OECD CONVENTION ON BRIBERY: A COMMENTARY (Mark Pieth et al. eds., 2007). The Anti-Bribery Convention has more signatories than the OECD itself. As of April 2012, with Russia ratifying the OECD Anti-Bribery Convention, there are thirty-nine ratified states. See ORG. FOR ECON. CO-OPERATION AND DEV., supra note 2.

33. Between the 1970s and 1980s, the World Bank also increasingly focused on the negative economic consequences of systemic corruption. ODD-HELGE FJELDSTAD \& JAN ISAKSEN, ANTI-CORRUPTION REFORMS: CHALLENGES, EFFECTS AND LIMITS OF WORLD BANK SUPPORT 1 (2008), available at http://siteresources.worldbank.org/EXTPUBSECREF/ Resources/Fjeldstad_anticorruption.pdf. The Bank focused on governance issues ("managerial capacity") as a polite euphemism for the embarrassing problem of demands for bribes by corrupt foreign officials, see discussion below. Later, around 2002 to 2004, the Bank expanded its focus to also include corrupt bribe payers (World Bank contractors) by enhancing its debarment sanctions. See THE WORLD BANK, WORLD BANK GROUP SANCTIONS REGIME - AN OVERVIEW 10-11 (2010), available at http://siteresources.worldbank.org/ EXTOFFEVASUS/Resources/Overview-SecM2010-0543.pdf.

34. See Kevin E. Davis, Why Does the United States Regulate Foreign Bribery: Moralism, Self-Interest or Altruism?, 67 N.Y.U. ANN. SURV. AM. L. 497, 503-04 (2012); see also Kevin E. Davis, Self-Interest and Altruism in the Deterrence of Transnational Bribery, 4 AM. L. \& ECON. REV. 314 (2002). While Professor Davis terms the development norm 'altruistic' it is certainly also possible to view economic development as self-interested by 
impact on democracies by undermining economic development was now included in the debate. ${ }^{35}$ The democracy and development norm has since become standard in FCPA discussions added to the earlier norms of morality, free competitive markets, and a level playing field for global trade. ${ }^{36}$

The democracy and development norms evolved during the 1970s and 1980s led by World Bank economists. ${ }^{37}$ During the 1960 s and 1970s, most multi-lateral development agencies, as well as researchers, avoided the embarrassing topic of corruption in developing economies. ${ }^{38}$ After a series of project failures, particularly in Africa, in 1983 the World Bank established a unit on governance. ${ }^{39}$ The World Bank's Legal Department of that era objected to what they viewed as potential political interference; ${ }^{40}$ the projects were cast in more politically neutral terms of "managerial capacities." ${ }^{41}$

From 1990 to 1996 , the unacceptable rate of investment failure, especially in Africa, and increasing pressure from donors for governance reform contributed to enhance focus on corruption problems among foreign officials. " "In October 1996, World Bank President James Wolfensohn set new precedents by speaking out against the "the cancer of corruption." "43 The World Bank's focus initially emphasized governance reforms on the demand side; by 2002 the Bank began to substantially strengthen debarment sanctions for supply side bribe payers. ${ }^{44}$

Another early major leader in articulating the negative impacts of corruption on economic development is the leading anti-bribery nongovernmental organization, Transparency International ("TI"). TI was

global trading powers. The House Report itself states that less corruption makes a nation more attractive for foreign investment, as does the Executive branch, which termed it a strategic and economic imperative. Id. at 504-05; see also H.R. REP. No. 105-802, at 10 (1998).

35. Spahn, Nobody Gets Hurt?, supra note 18, at 883 (discussing economics research regarding declining Gini coefficients).

36. President William J. Clinton: Statement on Signing the International Anti-Bribery and Fair Competition Act of 1998, The AmeriCan Presidency Project (Nov. 10, 1998), http://www.presidency.ucsb.edu/ws/index.php?pid=55254.

37. FJELDSTAD \& ISAKSEN, supra note 33.

38. Id.

39. See id; see also World Bank IndeP. Evaluation GrP., Public Sector Reform: WHAT WORKS AND WHY? 13 (2008), available at http://siteresources.worldbank.org/ EXTPUBSECREF/Resources/psr_eval.pdf (summarizing the World Bank's history of engagement with anti-corruption public governance reforms)

40. WORLD BANK INDEP. EVALUATION GRP., supra note 39, at 13.

41. Id. Other factors influencing these developments included the fall of communism and the need for second generation reforms. $I d$. at 14 .

42. Id.

43. Id.

44. See THE WORLD BANK, supra note 33. 
founded in 1993 by Peter Eigen, ${ }^{45}$ who saw the direct damage to local people done by corruption. While working for the World Bank in Africa, Eigen observed overpriced, unnecessary and damaging (so-called white elephant) projects designed to maximize rent-seeking (bribery) opportunities for corrupt local officials, which then increased the national debt of the looted and increasingly impoverished developing nation. ${ }^{46}$

Eigen left the World Bank to found Transparency International, originally based in Hamburg, Germany. In 1995, an intern at TI, Johan Graf Lambsdorff, ${ }^{47}$ developed a corruption perceptions index, which accidentally leaked to Der Spiegel, ${ }^{48}$ eventually becoming the influential and controversial Corruption Perceptions Index ("CPI") ranking the perception of various nations' propensity for corruption (demanding bribes). ${ }^{49}$ In 1999, TI began publishing the Bribe Payers Index ("BPI"), which ranked nations' multi-national corporations propensity for paying bribes to obtain business abroad. $^{50}$

\section{Respect for Local (Foreign) Law}

Although democracy and development norms became widely known and discussed during the 1990s, a fifth norm - respect for local (foreign) sovereigns - also emerged during the 1988 Amendments to the FCPA. Often overlooked in FCPA debates, the local law provision embodies a crucial norm about respect for foreign sovereigns. If the payment, gift, or hospitality was "lawful under the written laws" of the receiving official's state, it does not constitute a criminal bribe under the FCPA. ${ }^{51}$

The FCPA's local law provision establishes normative diversity regarding which transactions are classified as illegal "bribes" and which are classified as permissible "gifts." 52 Rather than imposing a one-size-fits-all US definition of "bribe" versus "gift," the FCPA places the power to define an acceptable gift in the hands of the local (foreign) legal system. ${ }^{53}$ The

45. Transparency International (TI), INT. Ass'N OF ANTI-CORRUPTION AUTHORITIES (Feb. 20, 2012), http://www.iaaca.org/AntiCorruptionAuthorities/ByIntemationalOrganizations/ NonGovernmentalOrganization/201202/ 20120220_807871.shtml.

46. Peter Eigen, Removing a Roadblock to Development, INNOVATIONS: TECH., GOVERNANCE, Globalization, Spring 2008, at 21-25, available at http://www.policyinnovations.org/ideas/ policy_library/data/01499/_res/id=sa_Filel/ INNOVATIONS_Eigen_TI.pdf.

47. JOHANN G. LAMBSDORFF, THE INSTITUTIONAL ECONOMICS OF CORRUPTION AND REFORM 161 (2007).

48. Eigen, supra note 46, at 31.

49. Corruption Perceptions Index, TRANSPARENCY INT'L, http://www.transparency.org/ research/cpi/ (last visited Jan. 23, 2013).

50. Transparency International (TI), supra note 45.

51. 15 U.S.C. $\S \S 78 d d-1(c)(1), 78 d d-2(c)(1), 78 d d-3(c)(1)(1998)$.

52. Id.

53. $I d$. 
local law provision establishes an objective, written standard for crossborder criminal law enforcement cooperation while permitting flexibility in local sovereign powers to regulate permissible foreign gifts and hospitality to their own officials in accordance with their own customs and values. ${ }^{54}$

Many nations have extensive, transparent written laws and regulations governing gifts to and entertainment of local officials. ${ }^{55}$ The local law provision provides global traders with a safer path to building relationships with foreign officials: Obey the local laws. Providing legal advice regarding local gifts and hospitality laws around the world has become an important compliance service offered by a variety of vendors. ${ }^{56}$

The provision is hard due to recognition in US criminal law of the diversity of values around the world regarding legitimate gifts and hospitality. The local law provision rebuts the charge that the FCPA is a form of US moral imperialism imposing its naïve values on hapless sovereigns abroad. The value choices at all times remain with local (foreign) sovereigns to define acceptable gifts and hospitality for their officials.

The US statute merely gives comity - legal respect to the foreign local laws. The truly remarkable act of permitting foreign sovereigns to define criminal law and domestic US tax treatment of gift and hospitality payments is international comity at a very high level. ${ }^{57}$ (Similar language was incorporated in the OECD Convention, Commentaries 7 and 8 , and explicitly in the domestic laws of several OECD member states. ${ }^{58}$ )

\section{E. Human Rights and the Rule of Law}

More recently a sixth norm emerged. As a global grassroots movement against corruption appears to be taking root, President Barack Obama in 2010 described corruption as "a profound violation of human rights." ${ }^{, 59}$ When kleptocratic elites give and take bribes with impunity, the

54. Id.

55. See, e.g, Spahn, Local Law Provisions, supra note 26, at 284-90 (discussing local regulations governing gifts and entertainment to officials in Japan and Hong Kong).

56. See, e.g, ETHIXBASE, https://ethixbase.com/ (last visited Jan. 23, 2013). EthiXbase is an online searchable subscription database, in English, of the local laws governing gifts and hospitality for over 135 nations.

57. Spahn, Local Law Provisions, supra note 26, at 270-76 (discussing the FCPA provision and the decision in United States v. Kozeny, 582 F. Supp. 2d 535 (S.D.N.Y. 2008) which interprets the FCPA local law defense).

58. Convention on Combating Bribery, supra note 2, at Commentaries 7-8. For a more detailed discussion of the OECD local law provisions, see Spahn, Local Law Provisions, supra note 26, at 267-69, 276-90.

59. Press Release, The White House, Remarks by the President at the Millennium Development Goals Summit in New York, New York (Sept. 22, 2010), available at http://www.whitehouse.gov/the-press-office/2010/09/22/remarks-president-millennium- 
rule of law itself is in peril. The impact falls most heavily on the poor in developing economies, ${ }^{60}$ on legitimate businesses trying to compete globally as if there were a rational competitive market, ${ }^{61}$ and on hapless consumers of sub-standard products of every class worldwide. ${ }^{62}$

Although the articulation of values has evolved over the thirty-five years of the FCPA, the American commitment to challenging corruption abroad as well as at home has not often wavered. ${ }^{63}$ While partisan battles are often very sharp, both Republican and Democratic administrations from President Gerald Ford (R) and President George W. Bush (R) to President Jimmy Carter (D) and President Barack Obama (D) have consistently committed their administrations to combatting bribery abroad. President Herbert Walker Bush (R) tried valiantly to overcome the resistance of our allies, and President Bill Clinton (D) succeeded in negotiating the OECD Anti-Bribery Convention. Opposing bribery, at home and abroad, is a fundamental, shared, non-partisan American value supporting a relatively consistent domestic economic and foreign policy strategy over thirty-five tumultuous years.

The FCPA model focuses solely on the supply side bribe payers. By disciplining our own influential US corporate citizens (corrupt bribe payers) first, rather than preaching at bribe takers (corrupt foreign officials), the FCPA is a classic example of walking the walk rather than just talking the talk. $^{64}$

Taking on the political, legal, and economic burden of changing what have been highly profitable bribery based business models for some of the most powerful economic actors in human history - US-based multinational corporations - has been no small task. Americans can be justly proud of our efforts.

development-goals-summit-new-york-new-york.

60. See developmental economics discussions, supra notes 33 and 37-41.

61. Spahn, Nobody Gets Hurt?, supra note 16, at 884-89.

62. Id. at 894-98.

63. But see, e.g., Richard L. Cassin, No Punishment for 'Hero' Giffen, THE FCPA BLOG (Nov. 22, 2012, 1:13 AM), http://www.fcpablog.com/blog/2010/11/22/no-punishment-forhero-giffen.html; David Glovin, Seven-Year Kazakh Bribery Case Ends with 'Sputtering' Misdemeanor Plea, Bloomberg (Aug. 6, 2010, 6:20 PM), http://www.bloomberg.com/ news/2010-08-06/oil-consultant-giffen-to-plead-guilty-to-misdemeanor-after-briberycharges.html. The United States was also very sharply criticized by UK's Lord Justice Thomas for weakness in the prosecution of the Delaware corporation Innospec. See infra notes 107, 110-12.

64. See, e.g., Matthew 7:3-5. 


\section{IMPLEMENTING GLOBAL ANTI-BRIBERY NORMS: SUPPLY SIDE (“ACTIVE”) PAYING BRIBES}

\section{A. OECD Anti-Bribery Convention Enforcement}

Explicitly modeled on the FCPA, the 1998 OECD Anti-Bribery Convention ("OECD Convention") is widely recognized as a landmark accomplishment in anti-bribery law reform. ${ }^{65}$ The OECD Convention requires signatory states to ban paying bribes (often described as supply side, or active bribery) to foreign officials to do business abroad. ${ }^{66}$ The Convention itself, like the FCPA, does not address receiving bribes (sometimes described as demand side or passive bribery discussed below in Section III).

Thirty-nine major economic powers have ratified the OECD Convention, including Russia, as of April, 2012. ${ }^{67}$ Brazil's ratification was effective in $2002 .^{68}$ The People's Republic of China ratified the United Nations Convention Against Corruption ("UN CAC", discussed below) and enacted domestic Chinese laws criminalizing bribery to foreign officials, ${ }^{69}$ but China has not yet joined the OECD Convention. ${ }^{70}$ China's energetic enforcement of its domestic anti-bribery laws is legendary, ${ }^{71}$ including

65. Eigen, supra note 46, at 29. Eigen, founder and Chair of the Advisory Counsel of Transparency International (a non-government organization), termed the OECD AntiBribery Convention a "quantum leap in the efforts to fight corruption." Id.

66. See Convention on Combating Bribery, supra note 2. The terms "active" (paying a bribe) and "passive" (receiving a bribe) bribery are frequently used in European law. See, e.g., Criminal Law Convention on Corruption, Council of Europe, Jan. 27, 1999, 38 I.L.M. 505 available at http://conventions.coe.int/Treaty/en/Treaties/Html/173.htm; Glossary, ANTI-CORRUPTION ReSOURCE CENTRE, http://www.u4.no/glossary/-(last visited Jan. 23, 2013).

67. ORG. FOR ECON. CO-OPERATION AND DEV., supra note 2.

68. Id.

69. Eric Carlson, China's Overseas Bribery Law One Year On, THE FCPA Blog (May 29, 2012, 3:28 AM), http://www.fcpablog.com/blog/2012/5/29/chinas-overseas-bribery-law-one-yearon.html. Beijing-based attomey Eric Carlson also advises foreign investors about Chinese enforcement of domestic anti-bribery laws. See Eric Carlson, China's Domestic Bribery Laws Impact Foreign Investors, THE FCPA BLOG (July 10, 2012, 12:28AM), http://www.fcpablog.com/ blog/2012/7/10/chinas-domestic-bribery-laws-impact-foreign-investors.html.

70. For more detailed analysis of China's anti-corruption enforcement, see Spahn, Local Law Provisions, supra note 26, at 258-61. See generally THE FCPA BLOG, CHINA ANTI-CORRUPTION HANDBOOK (Q4 2012), available at https://ethixbase.com/chinaanticomuptionhandbook (introduction by Richard L. Cassin). In addition, The FCPA Blog contributor Chua Guan Cheong, under the title "China Corruption Blotter," provides weekly updates regarding China's anti-corruption enforcement. See Entries by Chua Guan Cheong, THE FCPA BLOG, http://www.fcpablog.com/blog/author/chua (last visited Jan. 23, 2013).

71. See Margaret K. Lewis, Presuming Innocence, or Corruption, in China, 50 ColuM. J. Transnat'L L. 287 (2012); Minxin Pei, Explaining China's Corruption Paradox, Wall St. J. (June 11, 2012, 12:24 PM), http://online.wsj.com/article/ SB10001424052702303918204577446 
using the death penalty for bribery convictions (to date only for Chinese nationals). ${ }^{72}$ India, which is struggling with corruption issues in its domestic internal politics, ${ }^{73}$ is the sole major economic power without a statute criminalizing bribery abroad as of $2012 .{ }^{74}$ India finally ratified the UN CAC in $2011 .^{75}$

Signing a multi-lateral convention and enacting laws banning bribery abroad are not the same thing as effective enforcement. From 1998 until approximately 2005-06, there was little actual enforcement from OECD Convention signatories other than the United States. ${ }^{76}$ The first decade of the OECD Convention focused primarily on harmonizing formal written criminal and tax laws of the member states.

By 2007 the OECD Convention Working Group's focus shifted toward greater enforcement by nations other than the United States. ${ }^{77}$ Led by legendary Swiss criminal law professor, Dr. Mark Pieth, ${ }^{78}$ the OECD

021540060982.htmi?mod=googlenews_wsj (analyzing the harm done by corruption to China's economic development); see also YASHENG HUANG, SELling ChINA: ForeIGN DIRECT INVESTMENT DURING THE REFORM ERA (William Kirby ed., 2003) (discussing the negative impacts of corruption and foreign direct investment on the development of domestic entrepreneurs in China); Chua Guan Cheong, China Corruption Blotter, THE FCPA BLOG (Sept. 26, 2012, 12:07 AM), http://www. fcpablog.com/blog/2012/9/26/china-corruption-blotter-september-26-2012.html. The China Compliance Digest blog provides frequent descriptions in English of numerous Chinese corruption prosecutions. See, e.g., China Compliance Digest, ETHIXBASE, https:/ethixbase.com/ chinacompliancedigest/ (last visited Jan. 23, 2013). But see Andrew Brady Spalding, The Irony of International Business Low: U.S. Progressivism and China's New Laissez-Faire, 59 UCLA L. REv. 354 (2011) (suggesting that China takes a laissez-faire hands off approach to comuption enforcement).

72. See, e.g., In China, Death Row Billionaire Names Accomplices, THE FCPA BLOG (Feb. 29, 2012, 4:28 AM), http://www.fcpablog.com/blog/2012/2/29/in-china-death-rowbillionaire-names-accomplices.html; Richard L. Cassin, China's Clean Up Continues, THE FCPA BLOG (Sept. 10, 2010, 7:28 AM), http://www.fcpablog.com/blog/2010/9/10/chinasclean-up-continues.html. Australian citizen Stern Hu escaped the death penalty in China. See David Barboza, China Sentences Rio Tinto Employees in Bribe Case, N.Y. TiMEs (March 29, 2010), http://www.nytimes.com/2010/03/30/business/global/30riotinto.html?pagewanted=all\&_ $r=0$.

73. Hanishi T. Ali et al., Regional and Comparative Law- India, 46 INT'L LAw. 553, 553-56 (2012).

74. India is "examining" prohibiting bribery abroad. See id. at 554 .

75. Samuel Rubenfeld, India Ratifies UN Convention Against Corruption, WaLL. ST. J. BLoG (May 12, 2011, 5:54 PM), http://blogs.wsj.com/corruption-currents/2011/05/12/indiaratifies-un-convention-against-corruption; Ali et al., supra note 73, at 554.

76. See Spahn, Multi-Jurisdictional Bribery, supra note 20.

77. Id.

78. Mark Pieth is Professor of Criminal Law and Criminology at University of Basel, Chairman of the Board of the Basel Institute on Governance, Chairman of the OECD Working Group on Bribery in International Business Transactions, and Member of Swiss Federal Gaming Commission. See About Mark Peith, MARK PIETH: Professor OF CRIM. L. AND CRIMINOLOGY, http://www.pieth.ch/about_mark_pieth/(last visited Jan. 23, 2013).

Dr. Pieth has published extensively in English and in German on anti-bribery, as well as other multi-lateral criminal enforcement issues. See Publications, MARK PIETH: ProfESsOR 
Working Group's tour de table meetings of prosecutors from the thirty-nine signatory nations appear to be highly effective in coordinating enforcement efforts. $^{79}$

Germany led with its dramatic prosecution of Siemens (including dawn raids on Siemens' offices and homes of senior executives) ${ }^{80}$ in cooperation with the US Department of Justice. ${ }^{81}$ France referred a major bribery scandal involving several multi-national oil companies doing business in Nigeria to the United States as well as prosecuted its own French oil company (Elf-Aquitaine, now Total) ${ }^{82}$ The United Kingdom, which had suffered a very embarrassing initial failure to prosecute BAE bribery of Saudi royal family members due to political interference by then Prime Minister Tony Blair, ${ }^{83}$ was able to eventually sanction although not debar BAE in cooperation with the United States. ${ }^{84}$

of CRIM. L. AND CrIMINology, http://www.pieth.ch/nc/publications/ (last visited Jan. 23, 2013)

79. Abbott \& Snidal, supra note 20 , at $166-67$; See ORG. FOR ECON. CO-OPERATION \& DEV. WORKING GRP. ON BRIBERY, ANNUAL REPORT 26 (2008), available at http://www.oecd.org/dataoecd/21/24/44033641.pdf. For an example agenda, see ORG. FOR Econ. Co-Operation \& Dev., Prosecutors' Meeting: Detection, Investigation \& Prosecution of Foreign Bribery 24 (2007), available at http://www.oecd.org/dataoecd/ 8/37/39770035.pdf.

80. Siemens (Foreign Bribery Actions), THE TRACE COMPENDIUM, https://www.traceinternational2.org/compendium/view.asp?id=124 (last visited Jan. 23, 2013). The TRACE Compendium, with concise, accurate summaries and links to original source documents, is an excellent research tool for the Siemens case, as well as other bribery prosecutions. See Search Compendium, THE TRACE COMPENDIUM, http:/www.traceinternational.org/Knowledge/ Compendium.html (last visited Jan. 23, 2013).

81. See Press Release, Dep't of Justice, Siemens AG and Three Subsidiaries Plead Guilty to Foreign Corrupt Practices Act Violations and Agree to Pay $\$ 450$ Million in Combined Criminal Fines (Dec. 15, 2008), available at http://www.justice.gov/opa/pr/2008/ December/08-crm-1105.html ("The Department and the SEC closely collaborated with the Munich Public Prosecutor's Office in bringing these cases.").

82. See Halliburton/KBR, THE TRACE COMPENDIUM, https://www.traceintemational2.org/ compendium/view.asp?id=15 (last visited Jan. 17, 2013); Barbara Crutchfield George \& Kathleen A. Lacey, Investigation of Halliburton Co./TSKJ's Nigerian Business Practices: Model for Analysis of the Current Anti-Corruption Environment on Foreign Corrupt Practices Act Enforcement, 96 J. CRIM. L. \& CRIMINOLOGY 503, 507 (2006); see also Spahn, Multi-Jurisdictional Bribery, supra note 20, at 27-31 nn.139-58.

83. See Susan Rose-Ackerman \& Benjamin Billa, Treaties and National Security, 40 N.Y.U. J. INT'L L. \& POL. 437, 456-60 (2008); BAE Systems, THE TRACE COMPENDIUM, https://www.traceinternational2.org/compendium/view.asp?id=140 (last visited Jan. 23, 2013).

84. Settlement of BAE Systems Corruption Cases: Significant Issues of Concern, TRANSPARENCY INT'L (Feb. 11, 2010, 10:27 AM), http://www.transparencyusa.org/documents/TIUKBAE.pdf; see Jessica Tillipman, The Foreign Corrupt Practices Act \& Government Contractors: Compliance Trends and Collateral Consequences, BRIEFING PAPERS, Aug. 2011, at 13; see also Drury D. Stevenson \& Nicholas J. Wagoner, FCPA Sanctions: Too Big To Debar?, 80 FordHAM L. Rev. 775, 799, 801-02 (2011). 


\section{B. US Enforcement of the FCPA}

The OECD Convention agreement among the major economic powers set the stage for expanded US enforcement of the FCPA. During the administration of US President George W. Bush, enforcement of the FCPA accelerated exponentially both in terms of raw number of cases as well as ambitious prosecutions of complex grand corruption bribery schemes. ${ }^{85}$ Mark Mendelsohn, Deputy Chief of the US Department of Justice's Fraud Unit from 2004 to 2010 was widely respected during his tenure as the FCPA's leading prosecutor. ${ }^{86}$

As enforcement increased so did criticism particularly from nations such as India, among others, where elites are accustomed to receiving bribes from deep pocket foreign investors. ${ }^{87}$ These critiques progressed from crude versions of cultural relativism ${ }^{88}$ to claims of violated local sovereignty ${ }^{89}$ to more nuanced claims that anti-bribery laws are equivalent to 'sanctioning' nations where corruption is widespread. ${ }^{90}$

Enforcement patterns under the FCPA in particular have been criticized on several grounds ${ }^{91}$ including claims that the United States over-

85. Cortney C. Thomas, Note, The Foreign Corrupt Practices Act: A Decade of Rapid Expansion Explained, Defended, and Justified, 29 REv. LiTIG. 439, 439-40 (2010).

86. For a summary of some of Mark Mendelsohn's accomplishments enforcing the FCPA, see Richard L. Cassin, Goodbye, Mr. Mendelsohn, FCPA BLOG (Apr. 14, 2010, 7:18 AM), http://www.fcpablog.com/blog/2010/4/14/goodbye-mr-mendelsohn.html.

87. See Ali'a, supra note 5.

88. See Spahn, Moral Imperialism Critiques, supra note 6.

89. See, e.g., Extraterritorial Law and International Norm Internalization, 124 HARV. L. REV. 1280, 1285-90 (2011) (discussing the FCPA and the OECD Anti-Bribery Convention). This note critiques US and OECD jurisdiction because of "lack of consent" to jurisdiction by non-OECD nations. This argument inexplicably ignores specific statutory provisions of the FCPA that explicitly textually incorporate (foreign) local law into the US statute. The OECD Anti-Bribery Convention has similar provisions incorporating (foreign) local law explicitly. See Spahn, Local Law Provisions, supra note 26. "Non-consenting" nations merely need to enact their own domestic laws or regulations defining which gifts or entertainment their officials may legally accept from foreign business interests. This would provide a complete defense to prosecutions of bribe payers under the US FCPA or equivalent OECD AntiBribery Convention nations' statutes.

90. See generally Andrew Brady Spalding, Unwitting Sanctions: Understanding AntiBribery Legislation as Economic Sanctions Against Emerging Markets, 62 FLA. L. REV. 351 (2010). The highly debatable empirical evidence for the sanctions theory is examined infra note 99.

91. Mike Koehler, an assistant professor at Southern Illinois University Law School, is the most aggressive US critic of the FCPA in general and particularly of the US Department of Justice. Koehler is the self-proclaimed "FCPAProfessor" with his own blog established in 2009 and was a leading influence behind the failed 2010 US Chamber of Commerce efforts to "reform" the FCPA. See Dan Froomkin, Dems Ask U.S. Chamber If Firms That Bribed Are behind Its Push to Weaken Anti-Bribery Law, HufFINGTON Post (May 22, 2012, 8:55 PM), http://www.huffingtonpost.com/2012/05/22/foreign-corrupt-practices-act-chamber-of- 
enforces against "foreign" multi-national corporations ${ }^{92}$ and/or that the United States uses anti-bribery enforcement as a foreign policy tool to reward allies and punish enemies. ${ }^{93}$

An important quantitative analysis of US enforcement patterns under the FCPA by Nicolas Mclean was released in May 2012. ${ }^{94}$ This analysis of actual enforcement data provides an empirical basis for assessment of FCPA enforcement patterns. Examining cross-national patterns in FCPA enforcement from 2000 to $2011,{ }^{95}$ Mclean finds that enforcement actions are commensurate with both levels of US foreign investment and with variations in corruption levels. ${ }^{96}$ Whether the FCPA deters US foreign investment leaving corrupted nations vulnerable to so-called "black knights" ${ }^{\text {"97 }}$ is highly debatable under current economic studies. ${ }^{98}$ What empirical evidence does demonstrate is that bilateral frameworks for securities enforcement cooperation enhance FCPA enforcement. ${ }^{99}$

Foreign policy considerations were not significant factors in US

commerce-lobbying_n_1536739.html. Richard L. Cassin, who founded the influential FCPAblog.com in $200 \overline{7}$, has suggested that Koehler's academic interpretations of the FCPA (particularly the "foreign official" definition) are being tested by naïve criminal defendants through expensive and risky criminal trials, with some resulting in hefty prison sentences. Richard L. Cassin, On This Appeal Hang the Lives of Men, FCPA BLoG (May 22, 2012, 6:08 AM), http://www.fcpablog.com/blog/2012/5/22/on-this-appeal-hang-the-lives-of-men.html (citing seven and fifteen years in prison respectively in one of the recent test cases). (Disclosure: I am one of many "Contributing Editors" to the FCPA Blog, which is a purely honorary unpaid title. I do not engage in the practice of law for either defense or prosecution in bribery cases; I am a full-time tenured law professor.)

92. Using the term "foreign" for a "multi"-national corporation seems contradictory. By definition, the corporation operates in multiple jurisdictions. Equally puzzling is the persistence of the term "extra"-territorial for jurisdiction asserted over corporations seeking access to United States or United Kingdom capital markets or corporations seeking access to natural resources or labor supplies.

93. See, e.g., Balakrishnan Rajagopal, Corruption, Legitimacy and Human Rights: The Dialectic of the Relationship, 14 CONN. J. INT'L L. 495, 496 (1999). But see Spahn, Moral Imperialism Critiques, supra note 6, at 182-86 (rebutting the argument that the United States uses anti-bribery enforcement as a foreign policy tool to reward allies and punish enemies).

94. Nicolas M. Mclean, Cross-National Patterns in FCPA Enforcement, 121 YALE L. J. 1970 (2012).

95. Id. at 1989.

96. Id. at 2011 ("This relationship is robust to the inclusion of various controls, including GDP per capita and region-fixed effects.").

97. Spalding, supra note 71 , at 367.

98. See Mclean, supra note 94, at 1980 n.35, 2010-11 \& n.111; see also Nikolaus Schuttauf, Repeal Anti-Bribery Legislation? A Defense of Laws Promoting Clean Business and Transparent Governments, 46 NEW ENG. L. REV. 617, 633-41 (2012) (noting that antibribery laws are only one of several factors influencing foreign direct investment ("FDl")). Stability in government is a more significant influence on FDI than anti-bribery laws. Id. at 635-36. A reliable legal system with enforceable property rights, enforceable contract law and an effective judiciary are highly significant influences on FDI. Id. at 636-39. Finally, the health of the local population (human capital) influences FDI significantly. Id. at 639-41.

99. Mclean, supra note 94, at 2011. 
FCPA enforcement patterns Mclean's data showed. Examining matched voting patterns in the United Nations, military alliances, and democratic governance as proxies for US foreign policy considerations, ${ }^{100}$ Mclean finds that "U.S. foreign policy considerations are generally not associated with cross-national variation in FCPA enforcement, once other relevant factors (such as GDP per capita, regional fixed effects, FDI, and corruption levels) are controlled for." $" 101$

The data reveal that "the best predictor of the number of FCPA enforcement actions in a given country is the level of that country's experience with actual recorded corruption, rather than simply the relative level of corruption perceptions . . ."102 Enforcement of the FCPA from 2000 to 2011 appears to be consistent with the OECD Convention's requirement in Article 5 that prosecutions shall not be influenced by national economic or political interests. ${ }^{103}$

Some criticisms that anti-bribery law enforcement is politically biased are blatant excuses by self-interested corrupt bribe givers and takers. ${ }^{104}$ However, some of the politicization critique arises from weary cynicism after repeated, ineffective domestic corruption crackdowns. A very important article by Professor Xin Frank He of the University of Hong Kong, for example, examines in detail the ways that domestic anti-bribery crackdowns were used to increase bribe amounts and centralize control over bribe revenues in Beijing, China. ${ }^{105}$

Two recent US cases have generated fears that the commitment to anti-bribery law enforcement may not be as firm under the administration of President Barack Obama as it was under President George W. Bush. In an ironic turn of events, joint prosecutions of the Innospec cases by the United States and the United Kingdom ${ }^{106}$ revealed that the United Kingdom's Lord Justice Thomas viewed the United States as too soft in anti-bribery

100. Id. at 1992-93.

101. Id. at 2011.

102. Id.

103. Id.at 2003; ORG. FOR ECON. Co-OPERATION AND DEV., supra note 2, at art. 5.

104. The claims of outraged sovereignty by the President of Kazakhstan, for example, ring hollow given the scope of the bribes he personally took. See generally Elizabeth Spahn, Discovering Secrets: Act of State Defenses to Bribery Cases, 38 HofstRa L. Rev. 163 (2009) [hereinafter Spahn, Discovering Secrets]. Kazakhstan then tried to interfere directly and through lobbying in a domestic US criminal prosecution of a US citizen for violating US law, claiming Kazakhstan's sovereignty should be respected. Id. at 188-89.

105. See Xin Frank He, Sporadic Law Enforcement Campaigns as a Means of Social Control: A Case Study From a Rural-Urban Migrant Enclave in Beijing, 17 Colum. J. AsIAN L. 121 (2003), summarized in Spahn, Moral Imperialism Critiques, supra note 6, at 217-22; see also XIAOBO Lu, CADRES \& CORRUPTION: THE ORGANIZATIONAL INVOLUTION OF the Chinese Communist Party (2000); Huang, supra note 71; Yasheng Huang, CAPITALISM WITH ChINESE ChARACTERISTICS: ENTREPRENEURSHIP AND THE STATE (2008).

106. For a more detailed discussion of the Innospec cases during 2010-2012, see Spahn, Multi-Jurisdictional Bribery, supra note 20. 
enforcement effort. ${ }^{107}$ Innospec, a Delaware based corporation, manufactured a lead additive for gasoline. ${ }^{108}$ After US Clean Air Act reforms, Innospec's management looked for new markets for the lead-based additives. Innospec developed a business model from its London office to bribe legislators and other influential officials in Indonesia to delay adopting clean air regulations. ${ }^{109}$ The joint US-UK prosecutions coordinated both jurisdiction and penalties. ${ }^{110}$

In his sentencing opinion, UK Lord Justice Thomas termed the penalties agreed to between Innospec and the US Department of Justice "wholly inadequate" in light of the serious crimes Innospec committed." The financial penalties were relatively low because the firm faced insolvency, a justification Lord Justice Thomas found not sufficient, but in the interests of cooperation in the joint prosecution, he deferred to the US settlement terms. ${ }^{112}$

A second case of potential US enforcement weakness is the notorious Kazakhstan bribery case involving millions of dollars, furs, jewelry, and jet skis allegedly given in return for oil and gas contracts. ${ }^{113}$ After a seven-year effort to prosecute alleged bagman New York lawyer James Giffen, the case ended in 2010 with Giffen pleading to a misdemeanor tax charge, apparently after the Central Intelligence Agency refused to turn over documents in the case. ${ }^{114} \$ 84$ million in assets under the name of the

107. Id. at 35 n.190 (inter alia, bribing Indonesian politicians to delay clean air laws limiting lead additives to gasoline, damaging the people of Indonesia and the environment).

108. For a more detailed discussion of the various Innospec prosecutions which also included bribery in Iraq under Saddam Hussein and violations of US trade embargos with Cuba, see id. at 31-39 nn. 159-216.

109. Press Release, Serious Fraud Off., Innospec Limited Prosecuted for Corruption by the SFO (Mar. 18, 2010), available at http://www.sfo.gov.uk/press-room/latest-pressreleases/press-releases-2010/innospec-limited-prosecuted-for-corruption-by-the-sfo.aspx.

110. R v. Innospec Ltd., [2010] EW Misc (EWCC) 7, [19], [20] (Lord Thomas L.J.) (Eng.).

111. Id. at [40].

112. See id. at [41], [42], [43]. Lord Justice Thomas also expressed concern that insolvency of a corporation was not a sufficient reason to approve such a low fine, but he deferred to the United States' lead role in compliance and monitoring provisions. Id. at [48i], [49].

113. Nursultan Nazarbaev, President of Kazakhstan, and Nurlan Balgimaev, Oil Minister, allegedly took at least \$105 million cash laundered through seven US and Swiss banks, plus millions of dollars in jewelry, furs, jet skis and snowmobiles, tuition, vacations, and money to pay off credit cards. Spahn, Discovering Secrets, supra note 104, at 169-70.

114. See Letter from Preet Bharara, U.S. Attorney, to William J. Schwartz, Esq., Counsel for James H. Giffen (Aug. 6, 2010), available at http://www.justice.gov/criminal/fraud/fcpa/ cases/giffen/08-06-10giffen-plea-agree.pdf (becoming the Giffen Plea Agreement); Press Release, U.S. Attorney's Office, New York Merchant Bank Pleads Guilty to FCPA Violation; Bank Chairman Pleads Guilty to Failing to Disclose Control of Foreign Bank Account (Aug. 6, 2010), available at http://www.justice.gov/usao/nys/pressreleases/ August10/giffenjamespleapr.pdf; U.S. v. Giffen, 379 F. Supp. 2d 337, 341 (S.D.N.Y. 2004). 
Kazakhstan Ministry of Finance on deposit with Swiss bank Pictet \& Cie was apparently forfeited to the United States as part of Giffen's plea agreement. ${ }^{115}$

New York federal District Court Judge, William H. Pauley III, described Giffen as a "patriot" and a "hero," evidently because of Giffen's efforts to assist Cold War Soviet Jews emigrating during the 1980s. Judge Pauley's comments provoked widespread outrage (and thinly disguised glee from oligarchs abroad opposing corruption reform efforts ${ }^{116}$ ) by global anticorruption commentators. ${ }^{117}$

The Giffen outcome provides ammunition to those who claim the United States engages in selective prosecutions based on economic and political advantages in violation of the OECD Convention's Article 5 mandate. ${ }^{118}$ The Giffen case is equivalent to the embarrassment suffered by the UK in the Saudi/BAE case discussed above.

It is true that a CIA/strategic interest defense will not be available to ordinary bribe payers charged with FCPA violations. ${ }^{119}$ Mclean's quantitative analysis demonstrates that, on the whole, FCPA prosecutions

115. Kazakhstan Oil Mining / James Giffen - Mercator Corporation Case, STOLEN ASSET RECOVERY INITIATIVE, http://star.worldbank.org/corruption-cases/node/18529 (last visited Jan. 23, 2013).

116. Telephone Conference Call by Journalists in Asia with Robert O. Blake, Jr., Assistant Sec'y, Bureau of South and Cent. Asian Affairs, Wash., D.C. (Dec. 15, 2010), available at $\mathrm{http}: / /$ bishkek.usembassy.gov/tr_12_16_10.html.

117. See Lisa Brennan, In Stunning End to Kazakh Bribe Case, Judge Lauds Giffen as a 'Patriot', MAIN JustiCE (Nov. 19, 2010, 10:15 PM), http://www.mainjustice.com/ justanticorruption/2010/11/19/in-stunning-end-to-kazakh-bribe-case-judge-lauds-giffen-as-apatriot/; Steve LeVine, Was James Giffen Telling the Truth?, ForEIGN POLICY (Nov. 19, 2010, 4:04 PM), http://oilandglory.foreignpolicy.com/posts/2010/11/19/was_james_giffen_ telling_the_truth; Joanna Lillis, Kazakhgate Bribery Saga Fizzles Out amid Claims of Cold War Heroism, EuRASIANET (Nov. 23, 2010, 3:11 AM), http://www.eurasianet.org/node/ 62428; Richard L. Cassin, No Punishment for 'Hero' Giffen, FCPA BLOG (Nov. 22, 2010, 1:13 AM), http://www.fcpablog.com/blog/2010/1 1/22/no-punishment-for-hero-giffen.html.

118. Kazakhstan-USA: Judge Lauds James Giffen as "a Patriot," Ferghana News (Nov. 22, 2010), http://enews.fergananews.com/news.php?id=1929\&mode=snews.

According to Kommersant, US observers were shocked by such outcome. In
the interview to Voice of America Michael Perlis, which was involved in
the development of law on foreign corruption, said the verdict was 'the failure
of federal public prosecutors.' In the opinion of Mark Shulman, head of Pace
[U]niversity [L]aw [S]chool in New York, the pullback of US attorneys from
initial charges may be reasoned by recent negotiations between the USA and
Kazakhstan. After [a] few months of consultations [the] Kazakh government
agreed to open [a] few air-corridors for American troops in Afghanistan.

Id. In a statement to Kommersant, Mark Shulman said, "Sometimes US national interest may be more important than the arguments of public prosecution office." Id.

119. Mike Koehler, The Giffen Gaffe, FCPA Professor (Aug. 9, 2010, 12:02 AM), http://fcpaprofessor.blogspot.com/2010/08/giffen-gaffe.html. 
are not influenced by foreign policy considerations. ${ }^{120}$ The Giffen debacle may be an isolated failure, but real harm nevertheless is done to the idea of the rule of law: a neutral, professional, and independent legal system in the United States.

While the US judicial system has historically been relatively weak in general when faced with executive branch foreign policy or national security claims, ${ }^{121}$ in the bribery law reform context the consequences of this weakness are potentially significant. In the battle for hearts and minds, the effort to develop globally shared normative values that bribery is a crime and should be punished by law, exceptions for the rich and famous, for the influential and well-connected, and for those with large oil reserves are especially damaging.

The normative power of the anti-corruption reform effort is fundamentally one of fairness: equal justice under law. Criminal law applies not only to the poor, but to the rich and well-connected. This fundamental policy is undermined by exceptions based on economic advantage such as Kazakh or Saudi oil reserves.

Because of the negative impact on the credibility and legitimacy of bribery law enforcement, and in light of the understandable cynicism of those who have experienced repeated, ineffective domestic corruption crackdowns in nations such as China, Russia, Brazil, and India, the issue of politicized prosecutions is now central. This is especially true in nations where anti-corruption crackdowns have been used domestically as a tool of political discipline to punish political opponents while corruption of political allies goes unpunished.

As global anti-bribery enforcement efforts enter their second decade, potential problems of selective prosecutions, failure to prosecute, or underprosecution because of political or economic advantage in violation of the OECD Convention Article 5 are the most important issues to watch. Susan Rose-Ackerman and Benjamin Billa have an important article analyzing this issue in the context of the UK's BAE/Saudi problem. ${ }^{122}$ Mclean's quantitative analysis of the actual data is an invaluable tool to ensure that prosecutions go "where the evidence takes them" in a professional, politically neutral manner. ${ }^{123}$

The OECD Working Group is highly competent and well situated to

120. See supra notes $98-99$ and accompanying text.

121. See Louis Henkin, Foreign AfFaIRS AND the U.S. Constitution (1997); Harold Hongju Koh, Why the President (Almost) Always Wins in Foreign Affairs: Lessons of the Iran- Contra Affair, 97 YALE L.J. 1255, 1295-96 (1988); HaROLd HONGJU KOH, THE National Security Constitution: Sharing Power After the Iran-Contra Affair (1990). But see Daniel Abebe \& Eric A. Posner, The Flaws of Foreign Affairs Legalism, 51 VA. J. INT'L L. 507, 528-29 (2011).

122. Rose-Ackerman \& Billa, supra note 83 , at 456-60.

123. For a discussion of the Mclean analysis, see supra notes 94-96, 98-99. 
monitor Article 5 problems should they arise. In addition, enforcement cooperation between OECD Convention states is tempered by enforcement competition, including both assistance (as in the $B A E$ prosecutions) and transparent criticism (as in the Innospec cases).

The SEC adopted strict new transparency rules regulating payments by oil and gas companies and others in extraction mining industries in August 2012. ${ }^{124}$ The European Union is expected to follow soon. ${ }^{125}$ Canada, which itself has substantial natural resources, may also consider regulations requiring transparent payments. ${ }^{126}$ The new US regulations requiring transparency in payment for access to natural resources ${ }^{127}$ are the culmination of a long campaign by a coalition of several important nongovernmental organizations including Revenue Watch, ${ }^{128}$ Publish What You Pay, ${ }^{129}$ and Global Witness. ${ }^{130}$

\section{The Future of Supply Side Enforcement}

With the ratification of the UK Bribery Act, the US FCPA is no

124. See Press Release, Sec. and Exch. Comm'n, Disclosure of Payments by Resource Extraction Issuers (Aug. 22, 2012), available at http://www.sec.gov/rules/final/2012/34-67717.pdf; SEC Adopts Rules Requiring Payment Disclosures by Resource Extraction Issuers, U.S. SEC (Aug. 22, 2012), http://www.sec.gov/news/press/2012/2012-164.htm; Daniel Kaufmann, SEC's Day of Reckoning on Transparency: Dodd-Frank Section 1504 on Disclosure of Natural Resource Revenues, BROOKINGS (Aug. 21, 2012), http://www.brookings.edu/research/opinions/2012/08/21dodd-frank-kaufmann; C.M. Matthews, Initial Reactions: Businesses Score on Conflict Minerals, Lose on Extractive Industry Disclosures, WALL ST. J. (Aug. 22, 2012, 5:01 PM), http://blogs.wsj.com/comuption-currents/2012/08/22/initial-reactions-businesses-score-on-conflictminerals-lose-on-extractive-industry-disclosures/.

125. See Mark Tran, EU Legislatures Aim for Tougher Law on Oil, Gas and Mining Payments, THE GuARDIAN (Sept. 19, 2012, 2:00 AM), http://www.guardian.co.uk/globaldevelopment/2012/sep/19/eu-tougher-transparency-law-extractive. But see Christian Humborg, Why Doesn't Germany Support Detailed Transparency for the Oil, Mining Industries?, TRANSPARENCY INT'L (July 26, 2012), http://blog.transparency.org/2012/ 07/26/why-doesnt-germany-support-detailed-transparency-for-the-oil-mining-industries/.

126. See VAnCouver Sun, U.S. Adopts a Strong Anti-Corruption Measure -Will Canada?, Publish What You PAY (Aug. 26, 2012), http://www.publishwhatyoupay.org/ resources/us-adopts-strong-anti-corruption-measure-\%E2\%80\%94-will-canada.

127. See Frank Vogl, Sunshine on the Horizon for Oil, Gas and Mining Cash, TRANSPARENCY INT'L (Aug. 24, 2012), http://blog.transparency.org/2012/08/24/sunshineon-the-horizon-for-the-oil-gas-and-mining-cash/; ESCAPING THE RESOURCE CURSE (Macartan Humphreys et al. eds., 2007); TransParency INT'L, EXTRACTIVE INDUSTRIES TRANSPARENCY: THE BENEFITS OF EU LEGISLATION TO AFRICAN CITIZENS 2 (2012), available $a t \mathrm{http}: / / \mathrm{www}$.soros.org/sites/default/files/extractive-industry-transparency-20120626.pdf.

128. See generally REVENUE WATCH INST., http://www.revenuewatch.org/ (last visited Jan. 23, 2013).

129. See generally About $U s$, PUBLISH WHAT You PAY, http://www.publishwhatyoupay.org/ about (last visited Jan. 23, 2013).

130. See generally GLOBAL WITNESS, http://www.globalwitness.org/ (last visited Jan. 23, 2013). 
longer the benchmark for anti-bribery law enforcement. The UK Bribery Act of 2010, which finally took effect in 2012, is now the strictest and most feared criminal anti-bribery law. It prohibits both supply (active/paying) and demand (passive/taking) side bribery in addition to prohibiting business to business (B2B/commercial) bribery. ${ }^{131}$ Nevertheless, US FCPA enforcement will not abate in the foreseeable future. Prosecuting complex grand corruption global bribery conspiracies requires significant prosecutorial resources and expertise. Although the FCPA statute itself is significantly weaker than the UK Bribery Act, the expertise of enforcement personnel in the US Department of Justice is still more developed than the UK's Serious Fraud Office as of 2012. ${ }^{132}$ German prosecutors have been increasingly effective in enforcement as well. ${ }^{133}$ China has also prosecuted foreign business personnel, although not as vigorously as it prosecutes Chinese officials taking bribes. ${ }^{134}$ French courts recently affirmed the largest fine in a French corruption case in the amount of 630 million Euros. ${ }^{135}$

The 2012 Transparency International Progress Report for OECD Convention Enforcement shows some improvement. Canada, Austria, and Australia are the most improved from the prior report. ${ }^{136}$ Laggards (no

131. While detailed examination of the UK Bribery Act is beyond the scope of this article, the article by Bruce Bean and Emma H. MacGuidwin, Unscrewing the Inscrutable: The UK Bribery Act 2010, in this Indiana International \& Comparative Law symposium issue examines the UK Bribery Act in detail. 23 IND. INT'L \& COMP. L. 63 (2013). See also, e.g., Jon Jordan, Recent Developments in the Foreign Corrupt Practices Act and the New UK Bribery Act: A Global Trend towards Greater Accountability in the Prevention of Foreign Bribery, 7 N.Y.U. J. L. \& Bus. 845, 864-65 (2011); Jon May, The New British Invasion: Will the U.K. Bribery Act of 2010 Eclipse the FCPA?, CHAMPION, 28, 29 (Mar. 2012); F. Joseph

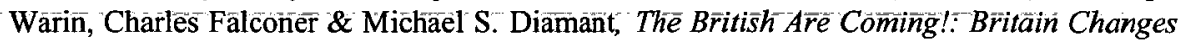
Its Law on Foreign Bribery and Joins the International Fight Against Corruption, 46 TEX. INT'L L.J. 1, 8 (2010).

132. The saga of the UK's SFO has been checkered, even before the BAE/Saudi scandal. More recently the SFO has faced potentially crippling budget cuts, which may render the Bribery Act ineffective in terms of actual enforcement. Alistair Craig, U.K. Anti-Corruption Enforcement Threatened by Budget Cuts, FCPA BLOG (Sept. 27, 2012, 5:45 AM), http://www.fcpablog.com/ blog/2012/9/27/uk-anti-corruption-enforcement-threatened-by-budget-cuts.html.

133. In 2011, German prosecutors recovered a $€ 149$ million fine against Ferrostaal for bribery in the sale of submarines to Greece. Leslie A. Benton et al., Anti-Corruption, 46 INT'L LAW. 353, 364 (2012).

134. Australian CEO Matthew $\mathrm{Ng}$ was sentenced by the Guangzhou Intermediate Court to thirteen years in Chinese prison for bribery and embezzlement. Id. at 363 .

135. Id. at 364 . The French case involved bribery in the sale of frigates to Taiwan; the case was over twenty years old. Id.

136. Compare Fritz Heimann \& Gillian Dell, Exporting Corruption? Country ENFORCEMENT OF THE OECD ANTI-BRIBERY CONVENTION PROGRESS REPORT 6, 12-14, 16-17 (2012), available at http://www.transparency.org/whatwedo/pub/exporting_corruption country_enforcement_of the_oecd_anti_bribery_conventio, with FRITZ HEIMANN ET AL., PROGRESS REPORT 2011: ENFORCEMENT OF THE OECD ANTI-BRIBERY CONVENTION 8-9 tbl.A 
enforcement) in foreign bribery prosecutions continue to be Ireland, Poland, Czech Republic, South Africa, Israel, Greece, New Zealand, and Estonia. ${ }^{137}$ Russia, having joined the OECD Anti-Bribery Convention in 2012, will be watched with great interest world-wide.

Although the raw number of lagging enforcement nations is high, most of them with the exception of Brazil ("little enforcement") are relatively smaller economies. In terms of percentage of world exports, nineteen nations comprising fifty-three percent of world exports are classified as active or moderate enforcers as of $2012 .^{138}$ This is up slightly from the 2011 report. ${ }^{139}$ It is also important to note that raw counts of cases prosecuted may not reflect enforcement effectiveness if states are pursuing very complex grand corruption bribery cases.

Where one nation proves unable or unwilling to enforce anti-bribery laws against favored national champion corporations (in violation of Article 5 's prohibition against political or economic favoritism in prosecutions), other nations can and do step up. ${ }^{140}$ Enforcing against 'foreign' ${ }^{141}$ multinationals is not only possible but now relatively frequent under the OECD Convention. ${ }^{142}$ Jurisdiction under the domestic statutes of active enforcers such as the United States and now the UK is quite broad. ${ }^{143}$

Enforcement competition between nations, including but not limited to OECD Convention signatories, is likely to increase as revenue starved states look to large fines and penalties available under domestic anti-bribery criminal statutes. ${ }^{144}$ In addition, the expansion of whistleblower bounties in the United States ${ }^{145}$ provides a lucrative path toward leveling the playing

(2011), available at http://www.transparency.org/whatwedo/pub/progress_report_2011_ enforcement_of_the_oecd_anti_bribery_convention.

137. HEIMANN \& DELL, supra note 136, at 6; Fighting Foreign Bribery: Prosecutions Making It Harder for Companies, TRANSPARENCY INT'L (Sept. 6, 2012), http://www.transparency.org/news/ feature/fighting_foreign_bribery_prosecutions

_making_it_harder_for_companies.

138. HEIMANN \& DELL, supra note 136, at 6.

139. Sixteen nations comprising fifty percent of world exports were active or moderate enforcers according to the 2011 report. HEMANN \& DELL, supra note 136, at 5.

140. For example, the United States assisted the United Kingdom in prosecuting BAE despite domestic political interference by Prime Minister Blair. See supra notes 83-84. For further development of the enforcement competition argument, see Spahn, MultiJurisdictional Bribery, supra note 20.

141. See supra note 92.

142. See supra notes 80-81 and accompanying text (discussing the Siemens case).

143. See, e.g., Extraterritorial Law and International Norm Internalization, supra note 89, at 1285-90 (2011) (discussing the FCPA and the OECD Anti-Bribery Convention).

144. However, it should be noted that under the FCPA fines and penalties are paid into the general Treasury funds rather than retained by the enforcing agencies. Mclean, supra note 94 , at $1978 \mathrm{n} .28$.

145. See Susan Rose-Ackerman \& Sinead Hunt, Transparency and Business Advantage: The Impact of International Anti-Corruption Policies on the United States National Interest, 67 N.Y.U. ANN. SURV. AM. L. 433, 448 (2012); Bruce W. Klaw, A New Strategy for Preventing Bribery and Extortion in International Business Transactions, 49 HARV. J. ON 
field against unfair competition from those continuing to cling to old bribeabroad business models.

In the event that enforcement competition proves insufficient to change bribe-abroad business models, debarment remedies which have to date been relatively under-deployed, appear to be coming to the forefront. The much-touted mandatory debarment sanction of the European Union has yet to be deployed frequently ${ }^{146}$ as plea agreements may be carefully structured to avoid it. ${ }^{147}$ The US debarment process is not especially effective at this point in time. ${ }^{148}$ Serious debarment action currently seems to be from the multi-lateral lending banks.

The World Bank, in particular, appears to be effectively increasing the likelihood of debarment sanctions against contractors for paying bribes. ${ }^{149}$ The World Bank's Sanctions Regime adopted its current twotiered structure in 2004 based on the recommendations of the 2002 Thornburgh Report. ${ }^{150}$ The 2007 Volker Recommendations further strengthened the sanctioning structures. ${ }^{151}$ Early temporary suspension was adopted in 2009 and other important reforms tightened standards and closed loopholes in 2010..$^{152}$

LEGIS. 303, 318-19 (2012); Gideon Mark, Private FCPA Enforcement, 49 AM. Bus. L.J. 419, 444-47 (2012); Joe Androphy et al., The Intersection of the Dodd-Frank Act and the Foreign Corrupt Practices Act: What All Practitioners, Whistleblowers, Defendants and Corporations Need to Know, 59 THE ADvoc. 19, 19-21 (2012).

146. See TRANSPARENCY INT'L, Recommendations FOR THE DEVElopment and IMPLEMENTATION OF AN EFFECTIVE DEBARMENT SYSTEM IN THE EU 2-3 (2006), available at $\mathrm{http}: / /$ www.eib.org/attachments/strategies/TI_EU_debarment_recommendations.pdf; see also Sope Williams, The Mandatory Exclusions for Corruption in the New EC Procurement Directives 31 E.L. REv. 711 (2006); Sue Arrowsmith et al., Self-Cleaning as a Defence to Exclusions for Misconduct-An Emerging Concept in EC Public Procurement Law?, 18 Public Procurement L. Rev. 257 (2009). My thanks to Jessica Tillipman for this research.

147. See Peter B. Clark \& Jennifer A.-Suprenant,-Siemens-Potential Interplay of FCPA Charges and Mandatory Debarment under the Public Procurement Directive of the European Union, in AM. BAR Ass'N CTR. FOR CONTINUING LEGAL EdUC. NAT'L INST., WHITE COLLAR CRIME, at B-74, B-75, B-76 (2009), available at http://www.americanbar.org/content/dam/aba/events/ criminal_justice/London/Session1_Clark_Siemens.authcheckdam.pdf.

148. See Tillipman, supra note 82 (providing an overview of the US debarment procedures); see also Drury D. Stevenson \& Nicholas J. Wagoner, FCPA Sanctions: Too Big To Debar?, 80 FORDHAM L. REV. 775 (2011).

149. Sanction Systems at the World Bank, THE WORLD BANK, http://web.worldbank.org/WBSITE/EXTERNAL/EXTABOUTUS/ORGANIZATION/ORGUN ITS/EXTOFFEVASUS/0, menuPK: 3601066 pagePK:64168427 piPK:64168435 theSitePK: 3601046,00.html (last visited Jan. 23, 2013).

150. The World Bank, World Bank Group Sanctions Regime - An Overview 10-11 nos.1, 3-4 (2010), available at http://siteresources.worldbank.org/EXTOFFEVASUS/ Resources/Overview-SecM2010-0543.pdf.

151. Id. at $12-13$ no. 10 .

152. Id. at 13-16 nos.13-25. For a truly intimidating flow chart of the Sanctions Procedures, see THE WORLD BANK, SANCTIONS SYSTEM Flow ChART, available at http://siteresources.worldbank.org/EXTOFFEVASUS/Resources/ETS_Flowchart_Version_ 10.20.10.pdf. 
Another major breakthrough occurred as the influential Regional Development Banks ${ }^{153}$ recently joined together in a landmark effort to coordinate their efforts for mandatory cross-debarment of contractors violating anti-bribery provisions of their contracts. ${ }^{154}$ One hundred and eleven firms and individuals had been cross-debarred between 2010 when the agreement was signed and April, 2012. ${ }^{155}$ A list of currently debarred firms and individuals is available, for free, on the World Bank's website. ${ }^{156}$ Although in depth examination of the Regional Development Banks' and the World Bank's sanctions efforts is beyond the scope of this article, it is an emerging topic in global anti-corruption law and currently under-written in the legal scholarship. ${ }^{157}$

The multi-pronged supply side enforcement strategy of the FCPA, with the new SEC Extractive Industries transparency regulations, and OECD Convention cooperative and competitive enforcement by thirty-nine economic powers, augmented by increased potential for debarment from the World Bank and the Regional Development Banks, have real potential to reduce both the frequency and the amounts of bribery abroad over time.

As loopholes are shut on the supply side for bribe payers, threats from corrupt foreign officials demanding bribes become increasingly empty. "Bribe me or I'll take my country's business elsewhere" is an empty threat if there is nowhere else to take their corrupt demands. Selling out your country for personal gain becomes more difficult when there are fewer buyers.

153. The cross-debarment agreement includes the African Development Bank, the Asian Development Bank, the European Bank for Reconstruction and Development, the InterAmerican Development Bank Group, and the World Bank. Press Release, Transparency Int'l, TI-USA Welcomes Multilateral Development Banks' Cross-Debarment Agreement (Apr. 9, 2010), available at http://www.transparency-usa.org/documents/4-910TIUSAReleaseonCrossDebarment.pdf.

154. THE WORLD BANK, supra note 150, at 16-17 no.26.

155. Stephan Zimmerman, Cross Debarment Two Years On, TRACE Blog (Apr. 11, 2012), http://traceblog.org/2012/04/11/cross-debarment-two-years-on/.

156. See World Bank List of Ineligible Firms \& Individuals, THE WORLD BANK, http://web.worldbank.org/external/default/main?theSitePK=84266\&contentMDK=64069844 \&menuPK=116730\&page $\mathrm{PK}=64148989$ \&piPK $=64148984$ (last visited Jan. 17, 2013); see also Evaluation and Suspension Officer Determinations in Uncontested Proceedings, THE WORLD BANK, http://go.worldbank.org/G7EO0UXW90 (last visited Jan. 23, 2013).

157. See Todd J. Canni, Debarment is No Longer Private World Bank Business: An Examination of the Bank's Distinct Debarment Procedures Used for Corporate Procurements and Financed Projects, 40 PUB. CONT. L.J. 147 (2010); Susan RoseAckermann, The Role of the World Bank in Controlling Corruption, 29 LAW \& POL'Y INT'L Bus. 93 (1997); Bruce Zagaris \& Shaila Lakhani Ohri, The Emergence of an International Enforcement Regime on Transitional Corruption in the Americas, 30 LAW \& POL'Y INT'L Bus. 53 (1999); Stuart H. Deming, Anti-Corruption Policies: Eligibility and Debarment Practices at the World Bank and Regional Development Banks, 44 INT'L LAW. 871 (2010). 


\section{IMPLEMENTING Global ANTI-BRIBERY Norms: DEMAND SidE ("PASSIVE") TAKING BRIBES}

One frequent criticism of both the US FCPA and the OECD AntiBribery Convention is that unlike the new UK Bribery Act, ${ }^{158}$ neither of the older legal regimes address the demand side of bribery transactions (corrupt foreign officials taking bribes is sometimes also termed 'passive' bribery). ${ }^{159}$ Business people frequently view demands from officials for payments, gifts, and hospitality as a form of 'extortion' ${ }^{160}$ and view themselves as victims twice over - once from a greedy foreign official and a second time from prosecutors in their home state. It seems deeply unfair that bribe payers go to jail, while bribe receivers continue their crimes with impunity, enjoying lavish lifestyles with the proceeds of their crimes.

The term 'extortion' has a very specific legal meaning under both the US FCPA and the OECD Anti-Bribery Convention. 'Extortion' under current US FCPA law does not extend to threats to economic or business advantage (pay me or I'll take my business elsewhere); under current US FCPA law, true extortion is limited to threats of violence (pay me or I'll blow up your oil rig). ${ }^{161}$ Commentary 7 of the OECD Anti-Bribery Convention also specifically excludes defenses based on threats to business advantage. ${ }^{162}$ This is a very important legal distinction as Russia enters the OECD Convention because older Soviet-style legal systems often permitted bribery defenses based on economic or business threats, while the US and

158. Jordan, supra note 131 , at 864 .

159. Sometimes, of course, the official taking bribes is not passive at all; he or she is demanding and perhaps even threatening unless bribes are paid. Sometimes, of course, the bribe payer is initiating and pushing the corrupt payment on a foreign official.

160. See Klaw, supra note 145, at 320-24. Professor Klaw of South Korea argues for including an economic extortion defense to the FCPA based on comparisons with domestic US bribery laws. He disagrees with the holding of the Kozeny court limiting extortion under the FCPA to violent situations and excluding economic threats. Id. at 333-35. Professor Klaw does not address the OECD Convention Commentary 7, which also excludes economic threats as a defense. Like Professor Yockey discussed below, Klaw relies on a pre-Kozeny, pre-OECD Convention law review article not purporting to address the specialized language of the FCPA to define extortion. Id. at n. 125 (citing James Lindgren, The Elusive Distinction between Bribery and Extortion: From the Common-Law to the Hobbs Act, 35 UCLA L. REv. 815,825 (1988)). See also Joseph W. Yockey, Solitication, Extortion, and the FCPA, 87 NOTRE DAME L. REv. 781, 795-800 (2011). Yockey apparently relies on a 1993 article defining extortion which pre-dates both the Kozeny case and the OECD Convention provisions discussed below. Id. at $\mathrm{n} .67$ (citing James Lindgren, The Theory, History, and Practice of the Bribery-Extortion Distinction, 141 U. PA. L. REv. 1695, 1699 (1993)). Yockey apparently also disagrees with the opinion in the Kozeny case. Id. at 817.

161. US v. Kozeny, 582 F. Supp. 2d 535, 538-40 (S.D.N.Y. 2008). For more detailed discussion of the "extortion" issue under both the FCPA and the OECD Convention, see Spahn, Local Law Provisions, supra note 26, at 273-76.

162. ORG. FOR ECON. CO-OPERATION AND DEV., supra note 2, at 14-19. 
OECD systems limit extortion defenses to threats of violence. ${ }^{163}$

The frustration that enforcement is focused primarily on the supply side of bribe payers is shared by multi-national corporations as well as exploited local people directly suffering under systemically corrupted regimes. There is some reason to hope that increasing global supply side enforcement against bribe payers has now set the stage for serious enforcement efforts on the demand side of corrupt officials.

\section{A. US Enforcement Against Demand Side Bribe Takers}

Domestic US law provides limited avenues for addressing demandside crimes where the official is foreign. Although the FCPA itself does not assert jurisdiction over corrupt foreign officials taking bribes, the United States recently used money laundering criminal statutes to reach three foreign government official bribe takers and their assets in the Haiti Telecoms cases. ${ }^{164}$

A second tool under US law is Presidential Proclamation 7750 (President George W. Bush, Republican), which allows the US Department of State to deny visas to corrupt foreign officials, their families and friends. ${ }^{165}$ Because US law requires secrecy in visa matters ${ }^{166}$ observers are hard-pressed to determine whether and how frequently this power is actually used. A WikiLeaks document did disclose a memo recommending

163. Spahn, Local Law Provisions, supra note 26, at 276, 281-83.

164. The United States Convicted Haitian telecommunications officials Robert Antoine, Jean Rene Duperval, and Patrick Joseph were convicted of laundering bribe money. Antoine received a reduced sentence of eighteen months for cooperation with the US prosecution. Judgment, United States v. Antoine, No. 1:09-21010-CR-M ARTINEZ-3 (S.D. Fla., May 29, 2012) available at http://www.fedseclaw.com/uploads/file/Antoine_2012_05_29_Amended_ Judgment.pdf; William McGrath, FCPA Cooperation: Robert Antoine Receives a Sentence Reduction in Haiti Teleco, FEDERAL SECURITIES LAW BLOG (June 1, 2012), http://www.fedseclaw.com/2012/06/ articles/foreign-corrupt-practices-act-1/fcpa-cooperationrobert-antoine-receives-a-sentence-reduction-in-haiti-teleco/\#axzz28ibVOcFk. Duperval was sentenced to nine years in US prison. Press Release, Dep't of Justice, Former Haitian Government Official Sentenced to Nine Years in Prison for Role in Scheme to Launder Bribes (May 21, 2012), available at http://www.justice.gov/opa/pr/2012/May/12-crm-656.html. Joseph received a one year and one day sentence. C.M. Matthews, Haitian Official Gets 1 Year in Florida Telecom FCPA Case, WALL St. JouRnAL (July 9, 2012, 3:20 PM), http://blogs.wsj.com/corruption-currents/2012/07/09/haitian-official-gets-1-year-in-floridatelecom-fcpa-case/. For an overview of the various prosecutions in the Haiti telecommunications bribery cases in which a Miami based company bribed Haitian government officials, see Haiti Teleco, The TRACE COMPENDIUM, https://www.traceinternational2.org/ compendium/view.asp?id=38 (last visited Jan. 23, 2013).

165. Presidential Proclamation 7750 To Suspend Entry as Immigrants or Nonimmigrants of Persons Engaged in or Benefiting from Corruption, 69 Fed. Reg. 2287, 2287-89 (Jan. 14, 2004), available at $\mathrm{http} / / / \mathrm{www} . g p o . g o v / f d s y s / p k g / F R-2004-01-14 / \mathrm{pdf} / 04-957 . p d f$.

166. 8 U.S.C. $§ 1184$ (2009); see Daniel M. Torrence, Note, Ideological Exclusions: A Prior Restraint Analysis, 11 Hastings Comm. \& ENT. L.J. 335, 359 (1989). 
denial of visas because of corruption for Kenyan citizen Aaron Gitonga Ringera and members of his family in 2009. ${ }^{167}$

It would be very helpful to global bribery law reform efforts if the secrecy requirements for visa denials under Presidential Proclamation $\mathbf{7 7 5 0}$ could be statutorily exempted. Publically naming kleptocrats as banned from entry to the United States would facilitate equivalent visa bans in other globally desirable locations as well. Limiting the abilities of kleptocrats, their families, ${ }^{168}$ and their cronies to enjoy their loot abroad will provide a significant crimp in their lifestyles. Cooperation between nations, especially those with highly desirable locations for the rich and infamous, is crucial.

France seized eleven luxury cars in downtown Paris belonging to the son of increasingly impoverished ${ }^{169}$ Equatorial Guinea's dictator Teodoro Obiang Nguema Mbasogo in August 2012. ${ }^{170}$ The son, Teodoro Nguema Obiang Mange ("Nguema"), is now wanted on money laundering charges in France. ${ }^{171}$ The US Department of Justice sought civil forfeiture of Nguema's allegedly stolen assets in $2011 .{ }^{172}$ The DOJ filed an in rem civil asset forfeiture suit against some of his US assets in the hilariously named "One White Crystal Covered 'Bad Tour' Glove" lawsuit on June 11, $2012 .{ }^{173}$ Among the named assets are the Michael Jackson glove, a $\$ 35$

167. Richard L. Cassin, Leaked Cable Reveals Kenya Visa Case, FCPA BLog (Sept. 6, 2011, 2:28 PM), http://www.fcpablog.com/blog/201 1/9/6/leaked-cable-reveals-kenya-visacase.html.

168. Perhaps an exception should be made for younger family members seeking educational opportunities abroad? Exposure to viewpoints that condemn looting one's native country for personal gain could be helpful to changing normative values in the next generation of local elites in developing nations. However, education sometimes provides a cover for lavish lifestyles as in the case of the notoriously flamboyant Teodoro Nguema Obiang Mange whose tuition at conservative Christian Pepperdine University was paid allegedly by bribe money from a Houston, Texas oil company doing business with his allegedly corrupt father. See infra notes 170-76.

169. See generally United Nations Dev. Programme, Human Development Report 2011 (2011), available at http://hdrstats.undp.org/images/explanations/GNQ.pdf. Equatorial Guinea ranks 136th out of 187 countries on the U.N. Human Development Index. Id. at 2.

170. Maia De La Baume, A French Shift on Africa Strips a Dictator's Son of His Treasures, N.Y. TIMES (Aug. 23, 2012) http://www.nytimes.com/2012/08/24/world/ europe/for-obiangs-son-high-life-in-paris-is-over.html.

171. See Teodoro Nguema Obiang Mbasogo/Teodoro Nguema Obiang Mangue, STOLEN ASSET RECOVERY INITIATIVE, http://star.worldbank.org/corruption-cases/node/18584 (last visited Jan. 23, 2013); Vivienne Walt, Teodorin Obiang: The Dictator's Son with a Malibu Mansion and a Warrant for His Arrest, TIME (July 16, 2012), http://world.time.com/ 2012/07/16/teodorin-obiang-the-dictators-son-with-a-malibu-mansion-and-a-warrant-for-hisarrest/.

172. Press Release, Dep't of Justice, Department of Justice Seeks to Recover More Than $\$ 70.8$ Million in Proceeds of Corruption from Government Minister of Equatorial Guinea (Oct. 25, 2011), available at http://www.justice.gov/opa/pr/2011/October/11-crm-1405.html.

173. The 118 page complaint details Nguema's extravagant lifestyle. Docket No. CV2: 
million Malibu mansion, and a fleet of luxury cars in California. ${ }^{174}$ Two Beverly Hills lawyers are also named for allegedly assisting Nguema in setting up shell accounts after banks refused to do business with him under his own name. ${ }^{175}$ The bribe money allegedly came from Houston, Texasbased oil and gas companies. ${ }^{176}$

The most promising tools currently available to punish, and one hopes eventually deter, grand corruption on the demand side are money laundering criminal prosecutions, ${ }^{177}$ asset recovery, ${ }^{178}$ and visa denials. Although no single tool will provide a silver bullet cure, as evinced by the continuing impunity of Zimbabwe's Robert Mugabe, ${ }^{179}$ they at least provide a start. The United States cannot do this alone; asset recovery cooperation, and perhaps competition, must be multi-lateral, particularly among more developed nations having desirable lifestyle options or reputations for bank secrecy.

For US FCPA defense lawyers, their frustrated corporate clients, and the US Chamber of Commerce lobby, it is important to move beyond parochial obsessions with domestic US law and complaints that they are victims. The most important enforcement developments today are coming from abroad, especially on the demand side.

\section{B. Multi-Lateral Efforts to Combat Demand Side Corruption: The Inter- American Convention Against Corruption and other Regional Conventions}

The very first multi-lateral anti-corruption convention addressed both supply-side (active) and demand-side (passive) bribery. The Inter-American Convention Against Corruption (IACAC) was adopted in $1996 .{ }^{180}$ Thirty-

\section{1-3582-GW-SS (on file with author).}

174. Guy Adams, Teodoro Nguema Obiang: Coming to America (to Launder his Millions?), THE INDEP. (June 16, 2012), http://www.independent.co.uk/news/world/americas/ teodoro-nguema-obiang-coming-to-america-to-launder-his-millions-7855043.html.

175. Id. The lawyers named are Michael J. Berger and George Nagler.

176. Id. Houston based oil company Ocean Energy allegedly paid Nguema's tuition at conservative Christian Pepperdine University in California. He dropped out after five months.

177. The OECD Financial Action Task Force is a leader in global anti-money laundering cooperation. See generally Who We Are, FIN. ACTION TASK FORCE, http://www.fatf-gafi.org/ (last visited Jan. 23, 2013).

178. The World Bank/United Nations Office of Drug and Crime Control joint project, the Stolen Asset Recovery Project ("StAR") is a leader in global asset recovery. See generally Home, STOLEN ASSET RECOVERY INITIATIVE, http://wwwl.worldbank.org/finance/star_site/ (last visited Jan. 23, 2013). See also Mark Vlasic \& Gregory Cooper, Beyond the Duvalier Legacy: What New "Arab Spring" Governments Can Learn from Haiti and the Benefits of Stolen Asset Recovery, 10 Nw. U. J. INT'L Hum. RTs. 19 (2011).

179. Mugabe, for example, purchased a house reputed to cost \$5.7 million USD in 2008 in lovely Hong Kong. Ishaan Tharoor, Mugabe's Home Away from Zimbabwe: Hong Kong?, TIME (Feb. 23, 2009), http:/www.time.com/time/world/article/0,8599,1881248,00.html.

180. Organization of American States, Inter-American Convention Against Corruption, 
four nations of the Organization of American States (OAS) ratified the Convention. ${ }^{181}$ Unlike the OECD Anti-Bribery Convention (adopted two years later in 1998), the IACAC was not primarily a US initiative, nor is it modeled on the US FCPA. The IACAC is generally viewed as a "personal triumph" for Venezuelan President Rafael Caldera. ${ }^{182}$

Both active and passive bribery are banned under Article VI of the IACAC. ${ }^{183}$ While the IACAC, like the OECD Convention, does require signatories to ban paying bribes abroad in Article VI (b), the primary focus of the Inter-American Convention is on the demand side of corrupt officials soliciting or accepting anything of value, Article VI (a). ${ }^{184}$ Preventive measures are at the forefront of the IACAC, which requires states to establish codes of conduct for public officials as well as systems to implement and enforce ethical standards in Article III. ${ }^{185}$

Public officials are required to disclose their assets, and explain any significant increase in assets that cannot reasonably be attributed to lawful earnings under Article IX (Illicit Enrichment). ${ }^{186}$ Requiring public officials to disclose and explain any significant increase in assets is a powerful weapon to address demand-side bribery. However, in many common law legal systems, placing the burden of proof on the defendant public official may violate presumption of innocence requirements. In civil law systems apparently this is less of a hurdle.

Asset recovery is also a major focus under the IACAC, as nations suffering from corrupt domestic officials seek to regain the loot - often stashed in banks abroad - usually in developed economies. New York, London, Dubai, Switzerland, the Channel Islands, Lichtenstein, Macau, and the Cayman Islands are all popular spots to stash illegal bribe assets. Article $\mathrm{XV}$ is dedicated to furnishing assistance among members for asset recovery. ${ }^{187}$ Article XVI prohibits bank secrecy as a rationale for denying

Mar. 29, 1996, 35 I.L.M. 724, available at http://www.oas.org/juridico/english/treaties/b58.html [hereinafter IACAC]. See also Anti-Corruption Portal of the Americas, ORG. OF AMERICAN STATES, http://www.oas.org/juridico/english/fightcur.html (last visited Jan. 17, 2013); Giorleny D. Altamirano, The Impact of the Inter-American Convention Against Corruption, 38 U. MIAMI INTER-AM. L. REV. 487 (2007); Bruce Zagaris, Developments in the Institutional Architecture and Framework of International Criminal and Enforcement Cooperation in the Western Hemisphere, 37 U. MIAMI INTER-AM. L. REV. 421 (2006).

181. Signatories and Ratifications B-58: Inter-American Convention Against Corruption, ORG. OF AMERICAN STATES, http://www.oas.org/juridico/english/Sigs/b-58.html (last visited Jan. 23, 2013). Six of the thirty-four are also signatories to the OECD Anti-Bribery Convention.

182. Zagaris, supra note 180 , at 506 ("Venezuelan President Rafael Caldera . . . had promoted adoption of the IACAC for many years following the failures of some of the major banks in Venezuela and allegations of corruption that led to those failures.").

183. IACAC, supra note 180 , art. Vl, para. 1.

184. Id.

185. Id., art. III, para. 1-3.

186. Id., art. IX.

187. Id., art. XV. 
information or assistance to a requesting State Party. ${ }^{188}$ (The OECD Financial Action Task Force ("FATF") has a vigorous global anti-money laundering program, ${ }^{189}$ and the World Bank's StAR asset recovery program under the UN Convention is discussed below).

With the primary focus on the demand side - public officials soliciting or accepting bribes - the IACAC statement of norms differs in emphasis from the FCPA. Where the FCPA emphasis is on global competition, the IACAC emphasizes economic development, which is particularly undermined by organized crime, especially in illicit narcotics. ${ }^{190}$ While the FCPA focuses on preventing deep-pocket global traders from paying bribes, the IACAC focuses on preventing public officials from soliciting bribes, and on recovering the proceeds of crime.

The IACAC is implemented through a follow-up mechanism known as MESICIC. ${ }^{191}$ Although MESICIC has official documents and materials available in English on its well-organized website, there is little independent research and analysis available from legal scholars. It would be exceptionally helpful as the global anti-corruption legal scholarship develops if legal scholars fluent in Spanish and Portuguese would research domestic implementation efforts of several of the IACAC provisions, including Article IX (Illicit Enrichment), Articles XV (Asset Recovery), and Article XVI (Bank Secrecy).

Because the IACAC is the oldest convention with these provisions, it has the most experience in implementation. Sharing information about the successes and failures, especially for provisions implementing disclosure of public officials' assets, and asset recovery will be very helpful for other nations under the United Nations Convention Against Corruption (see discussion below).

Other regional anti-corruption conventions were also adopted focusing on both supply- and demand-side bribery. The European Union adopted extensive anti-corruption provisions during the 1990s and the EU has very able legal scholars who are better situated than I to analyze them. ${ }^{192}$ The African Union also adopted a regional anti-corruption convention coming into force in 2006 , which has also been extensively

188. Id., art. XVI, para. 1.

189. Who We Are, supra note 177.

190. IACAC, supra note 180 (see specifically the Preamble).

191. Anti-Corruption Portal of the Americas, supra note 180; What is the MESICIC?, ORG. OF AMERICAN STATES, http://www.oas.org/juridico/english/mesicic_intro_en.htm (last visited Jan. 23, 2013).

192. See, e.g., Peter W. Schroth \& Ana Daniela Bostan, International Constitutional Law and Anti-Corruption Measures in the European Union's Accession Negotiations: Romania in Comparative Perspective, 52 AM. J. CoMP. L. 625 (2004); Laura Ferola, Anti-Bribery Measures in the European Union: A Comparison with the Italian Legal Order, 28 INT'L J. LEGAL INFO. 512 (2000). 
analyzed by able legal scholars. ${ }^{193}$

\section{Multi-Lateral Efforts to Combat Demand Side Corruption: the United Nations Convention Against Corruption}

While the IACAC was the first and served as a model, the real globalization of the movement to address demand-side corruption came through the United Nations Convention Against Corruption ("UNCAC"), which entered into force in $2005 .{ }^{194}$ As of December 2012, there are 165 States Parties and 140 Signatories to the UNCAC. ${ }^{195}$ The UN Convention addresses five topics: prevention, criminalization and law enforcement measures, international cooperation, asset recovery, and technical assistance and information exchange. Various forms of corruption such as trading in influence, abuse of power, and various acts of corruption in the private sector are also addressed.

In September, 2011, the UNCAC launched a sophisticated website with a searchable electronic database of corruption-related legislation and jurisprudence for over 175 countries. 196 "TRACK", the acronym for Tools and Resources for Anti-Corruption Knowledge, will greatly facilitate independent analysis of the progress in law reforms under UNCAC. The TRACK database permits searches by country, by Convention Article topic, by type of legal system, and by governance structure. TRACK also provides research and sharing information for anti-corruption practitioners, including enforcement agencies. ${ }^{197}$

The normative bases for UNCAC are similar to those of the InterAmerican Convention. ${ }^{198}$ Economic development, concerns about transnational organized crime, and commitment to the rule of law are among the major values articulated in the Preamble to the Convention. The

193. See John Mukum Mbaku, The International Dimension of Africa's Struggle against Corruption, 10 ASPER REV. INT'L Bus. \& TRADE L. 35, $61-67$ (2010); Lucky Biyce Jatto Jnr, Africa's Approach to the International War on Corruption: A Critical Appraisal of the African Union Convention on Preventing and Combating Corruption, 10 ASPER REV. INT'L Bus. \& TRAde L. 79, 82-94 (2010).

194. United Nations Convention Against Corruption, supra note 3; United Nations Convention Against Corruption; Contemporary Practice of the United States Relating to International Law, 98 AM. J. INT'L L. 169, 182 (Sean D. Murry ed., 2004).

195. United Nations Convention Against Corruption: UNCAC Signature and Ratification Status, supra note 3.

196. On Track Against Corruption, TRACK, http://www.track.unodc.org/Pages/ home.aspx (last visited Jan. 23, 2013).

197. Network of Practitioners, TRACK, http://www.track.unodc.org/Practitioners/Pages/ practitioners-networks.aspx (last visited Jan. 23, 2013).

198. See United Nations Convention Aganst Corruption, General Assembly RESOLUTION 58/4 OF 31 OCTOBER 2003, at 2, 5-6 (2004), available at http://www.unodc.org/ documents/treaties/UNCAC/Publications/Convention/08-50026_E.pdf; IACAC, supra note 180. 
role of anti-corruption norms in grassroots movements is rising; increasingly, they are seen as fundamental rights. ${ }^{199}$

Recovery of assets is a major concern for UNCAC countries pursuing the assets of former leaders and other officials accused of or found to have engaged in corruption. In cooperation with the World Bank, the StAR asset recovery project was launched, providing technical expertise to nations seeking to recover looted assets. ${ }^{200}$ The OECD and StAR issued an important joint report in March 2012 on identification and quantification of the proceeds of bribery. ${ }^{201}$ Asset recovery is, in my opinion, the most exciting area currently developing in global anti-corruption reforms on the demand (passive) side.

\section{CONCLUSION}

On the supply side, enforcement cooperation and competition among OECD Convention nations disciplining multi-national bribe payers appears to be highly effective. On the demand side, anti-money laundering law enforcement and facilitating asset recovery of bribe revenues as well as embezzled state assets will provide an economic incentive to reform systemically corrupted nations. If corrupt officials cannot safely stash their loot in First World banks, stocks, or real estate to ensure a comfortable lifestyle exit strategy for themselves, their family and friends, it may encourage legitimate rather than corrupt wealth acquisition. At least it will make it more difficult and risky for corrupt bribe takers and their clans to enjoy the stolen loot in desirable locations abroad.

Although thirty-five years may seem painfully slow, in comparison to other major global law reforms of profitable but unacceptable business models, it seems to be on track. The abolition of the transatlantic slave trade, a highly profitable business model, took about sixty years with Britain and especially the British Navy leading virtually alone while other nations, including the US and Brazil, lagged in enforcement until the very

199. See, for example, Juliet Sorenson's interesting article detailing the role of anticorruption norms in the Arab Spring revolutions and subsequent developments. Juliet Sorenson, Ideals without Illusions: Corruption and the Future of a Democratic North Africa, 10 Nw. U. J. INT'L HuM. RTs. 202, 207-08 (2012). Sorenson contrasts North Africa's struggles with corruption with the successful anti-corruption efforts of Botswana and Hong Kong. Id. at 223-31.

200. See Home, supra note 178; Open-Ended Intergovernmental Working Group on Asset Recovery, UNITED NaTIONS OFF. ON DRUGS AND CRIME, http://www.unodc.org/unode/ en/treaties/CAC/working-group2.html (last visited Jan. 17, 2013); Vlasic \& Cooper, supra note 178 , at $18-25$.

201. ORg. FOR ECON. Co-Operation AND DEV., IDENTICATION AND QUANITIFICATION OF THE PROCEEDS OF BRIBERY (2012), available at http://www.oecd.org/daf/ briberyininternationalbusiness/50057547.pdf. 
end of that era. ${ }^{202}$ Some African tribal chiefs who profited from the slave trade were slow to accept the demise of that now-discredited model of global trade. Some merchants adapted, finding less risky profits in other aspects of global trade (tea, spices, opium); other merchants were unable to adapt. $^{203}$ One transatlantic merchant slaver was eventually hanged by the United States as a pirate.

Bribery, like murder, rape, slavery or other crimes, will still occur despite criminal laws being vigorously enforced. Law cannot totally abolish criminal acts or catch every criminal. But laws do change as norms evolve. Increasingly people around the world understand that bribe givers and bribe takers are real criminals doing real harm to real people.

202. The analogy to the abolition of the transatlantic slave trade business model is developed in more detail in Spahn, Multi-Jurisdictional Bribery, supra note 20.

203. Professor Peter Henning compares dependence on bribery as a business model to drug addiction, very difficult to change. He holds out hope for rehabilitation efforts. Peter J. Henning, Corporate Criminal Liability and the Potential for Rehabilitation, 46 AM. CRIM. L. REv. 1437, 1428-29 (2009). 
, 